\title{
1. Setting the scene: European debates on collective redress in competition law
}

\section{PART I EU PRIVATE COMPETITION LITIGATION: INTRODUCTORY REMARKS}

\section{INTRODUCTION}

The viability and the feasibility of private enforcement of the EU Treaty competition rules (that is, Articles 101 and 102 Treaty on the Functioning of the European Union "TFEU" has been a "hot topic" for the European Commission as well as for the wider EU "legal community" for a number of years. These actions were initially envisaged as a means of supplementing the activity of the Directorate-General (DG) for Competition, at the time "overwhelmed" by its "exemption monopoly" under the old Implementing Regulation, by catching alleged infringements with which the Commission could not deal, due to the lack of "Community interest". It was only in 2001, with the Crehan preliminary ruling, ${ }^{1}$ that the Court of Justice of the European Union expressly recognized a cause of action for those aggrieved by the adverse consequences of cartel and, later, anti-competitive behaviour generally. Today, especially as a result of the Manfredi judgment, ${ }^{2}$ this cause of action is recognized to any person who can demonstrate to have been "injured" because of an infringement of the Treaty competition rules, thus paving the way for judicial proceedings to be commenced by a wider category of parties than the one envisaged in Crehan.

However, more than ten years since Crehan, the take up for civil actions brought either to claim damages or to seek injunctive relief against those responsible for anti-competitive behaviour having an

1 Case C-453/99, Courage v Crehan, [2001] ECR I-6297.

2 Case 295/04, Manfredi v Lloyd Adriatico Assicurazioni SpA, [2006] ECR I-6619. 
"appreciable effect" on the trade among Member States has been very limited. In 2004, the Ashurst Report, commissioned by the European Commission to investigate these issues, branded the system for the private enforcement of competition law "seriously underdeveloped" 3 and spanned a wave of consultation, culminating with the 2008 White Paper on Antitrust Damages. ${ }^{4}$ Among the ways in which the Commission thought that private competition claims could be enforced, the bringing of collective claims has featured prominently in the discussion, especially in view of the "diffuse" nature of antitrust damages, the link existing between the goals of "restoration" and that of enhancing the deterrence of Articles 101 and 102 TFEU, especially by supplementing the more "traditional" public enforcement activities. ${ }^{5}$

However, the initial impetus toward facilitating competition litigation via the EU-wide provision of collective proceedings before civil courts was met with concern and sometimes with outright opposition on the part of EU institutions and of the Member States, who were especially mindful of the need to avoid disrupting the inner coherence of their litigation systems. ${ }^{6}$ Against this background the 2011 Joint Information Note on Collective Redress represented a positive development: first of all it confirmed the EU Commission's commitment to engendering legal change aimed at boosting access to justice via group legal actions and, more widely, via collective mechanisms designed to afford relief of the

3 Study on the conditions of claims for damages in case of infringement of the EC competition rules, 31 August 2004, available at: http://ec.europa.eu/ competition/antitrust/actionsdamages/comparative_report_clean_en.pdf (hereinafter referred to as "Ashurst Report").

4 See 2004 Green Paper on damages action for the breach of EC competition rules, Sec(2005) 1732 final, available at: http://eur-lex.europa.eu/LexUriServ/ LexUriServ.do?uri=COM:2005:0672:FIN:EN:HTML (hereinafter referred to as "2004 Green Paper"); see also 2008 White Paper on damages actions for breach of the EC competition rules, SEC(2008) 406 final, available at: http://eurlex.europa.eu/LexUriServ/LexUriServ.do?uri=COM:2008:0165:FIN:EN:HTML (hereinafter referred to as "2008 White Paper").

5 See e.g. 2008 White Paper, para. 2.1.

6 See e.g. European Parliament resolution of 26 March 2009 on the White Paper on damages actions for breach of the EC competition rules, 2008/2154/ INI, available at: http://www.europarl.europa.eu/sides/getDoc.do?pubRef=-//EP// TEXT+TA+P6-TA-2009-0187+0+DOC+XML+V0//EN (hereinafter referred to as the "2009 European Parliament Resolution"), sections 4-6. 
injuries suffered by victims of practices with a widespread impact on society and the economy. ${ }^{7}$

Second, it showed that the Commission had been willing to take on board the concerns for maintaining the integrity of the rules on domestic litigation, which could have been put at risk by adopting measures for a "special competition class action" by shifting its approach towards a set of proposals for collective redress mechanisms that would be generally applicable to all "mass tort" cases, namely those torts originating from unlawful practices which affect numerous claimants and would be too small to be litigated individually. ${ }^{8}$ The purpose of this chapter will be, therefore, to trace the development of the EU debate on the role and function of collective litigation as well as, more generally, of the concept of "collective redress" in the area of EU competition law. It will examine the development of a right to damages arising from the consequences of prima facie anti-competitive behaviour; in that context, consideration will be given to the nature and characteristics of these losses as being "diffuse" in nature, and thereby affecting vast sections of society, and to the rules governing standing to sue.

Thereafter, the chapter will analyse the Commission's proposals for facilitating these actions, starting with the 2004 Green Paper on damages actions for the breach of EC competition rules and going all the way up to the 2011 Joint Information Note, mentioned above. It will be illustrated that while the discussion on the question of how to secure greater access to justice via collective litigation in "mass tort cases" has now decidedly veered towards having a "horizontal focus", it is still indispensable to reconcile whatever approach is adopted to deal with these issues with the demands of particular types of claims, including competition disputes. It is this question, ultimately, that this work seeks to answer, on the basis of the analysis of the US experience of class antitrust litigation as well as in light of the responses to the same question adopted by some of the EU Member States. Thus, after having outlined the structure of this work the remainder of this chapter will concentrate on some of the theoretical issues arising from the idea of 'collective action' generally, as well as in the more limited context of civil litigation, with a view to identifying what features group lawsuits should have in order to ensure greater and easier access to justice for would-be plaintiffs.

7 "2011 Joint Information Note: Toward a common European approach to collective redress", available at: http://ec.europa.eu/transparency/regdoc/rep/2/ 2010/EN/2-2010-1192-EN-1-0.Pdf (hereinafter referred to as the "2011 Joint Information Note").

8 See e.g. ibid., para. B.7. 


\section{THE ROAD IS LONG: EU PRIVATE COMPETITION ENFORCEMENT DEBATES AND THE ROLE OF COLLECTIVE LITIGATION}

\subsection{Private Competition Enforcement from the 1993 Notice to Modernization}

The genesis of the right to claim damages arising from the consequences of anti-competitive behaviour in the EU has been widely discussed and it is beyond the limits of this chapter to consider in detail the terms of such a wide-ranging debate. However, it is indispensable at this junction to consider briefly the key stages in the development of this cause of action, so that its importance and purpose can be properly assessed. Both the case law of the EU courts and the Commission's policy statements demonstrate a clear commitment to making the enforcement of Articles 101 and 102 TFEU before domestic courts more effective, so as to complement the public enforcement of these rules by the Commission itself and by the National Competition Authorities (NCAs). In the BRT $v$ $S A B A M$ preliminary ruling' ${ }^{9}$ the Court of Justice recognized that these provisions enjoyed direct effect and could therefore be relied on to establish rights that national courts had to protect, to the benefit of the effet utile of the Treaty as well as of the implementation of an EU-wide competition policy.

In the later Automec appeal decision ${ }^{10}$ the General Court held that by virtue of that direct effect, the jurisdiction to apply Articles 101(1) and 102 was shared between the Commission and the domestic courts and had to be exercised in accordance with principles of loyal cooperation. ${ }^{11}$ Thus, the Court of Justice held that the Commission had been fully entitled to reject a complaint as to the alleged existence of anticompetitive behaviour for lack of a "Community interest", ${ }^{12}$ inter alia, on the grounds that the complainant had already commenced judicial proceedings before a national judge. ${ }^{13}$ Furthermore, in the Masterfoods preliminary ruling the Court of Justice confirmed that by virtue of their direct effect, the national courts were responsible, together with the Commission, for the application of the Treaty competition rules to

\footnotetext{
Case 127/73, BRT v SABAM, [1974] ECR 313, paras 15-16.

Case T-24/90, Automec v Commission, [1992] ECR II-2223.

Ibid., para. 90.

2 Ibid., para. 85 .

13 Ibid., para. 94.
} 
individual cases ${ }^{14}$ and emphasized their obligation, according to the principle of loyal cooperation, not to depart from earlier Commission decisions adopted in relation to the same case pending before them in a specific case. ${ }^{15}$

That domestic courts should be jointly responsible for competition enforcement with respect to private disputes was openly acknowledged by the European Commission in its 1993 Notice on Cooperation with National Courts. ${ }^{16}$ In that document the Commission expressed the commitment to boosting the importance and the number of these actions by endorsing the General Court's position expressed in Automec, namely that domestic courts possessed "concurrent powers" to apply the Treaty competition rules to individual cases, except, of course, the exemption clause contained in Article 101(3). ${ }^{17}$ At the same time, however, the Notice emphasized that this task was substantially different from that incumbent on the Commission: whereas the latter was responsible for the setting up and the implementation of the EU competition policy, and in that context enjoyed the "monopoly" in the application of the "exemption clause" contained in Article 101(3) TFEU, the domestic courts were empowered, acting either proprio motu or if so asked by individual litigants, "to ensure the respect of the competition rules to the benefit" of the parties to a specific dispute. ${ }^{18}$

For this purpose, the Commission emphasized that the national judiciaries were only required to fulfil this task within the limits and the framework of their own national procedural rules. ${ }^{19}$ Thus, individual litigants were entitled to enforce their rights arising from the EU competition rules subject to the principles of practical possibility and of equivalence, ${ }^{20}$ by having "access to all procedural remedies provided" by national law at the same conditions as if an infringement of domestic law

14 Case C-344/98, Masterfoods Ltd v HB Ice Cream Ltd, [2000] ECR I-11369, paras 46-47.

15 Ibid., paras 49, 51-52; see also e.g. case C-243/89, Delimitis v Henninger Brau, [1991] ECR I-935, especially paras 44-48.

16 [1993] OJ C39/6.

17 Ibid., para. 14.

18 Ibid., para. 12.

19 Ibid., para. 17.

20 Ibid. 
had occurred ${ }^{21}$ and without making the exercise of EU law-based rights excessively difficult in practice. ${ }^{22}$

The 1993 Notice was regarded as a clear sign of the Commission's support for private competition claims, so as to protect the interests of those adversely affected by alleged anti-competitive behaviour and to supplement its own enforcement activity. ${ }^{23}$ However, the 1993 Notice failed to "spur on" any serious development in this area. According to a study conducted by Rodger, ${ }^{24}$ about 90 cases were lodged in British Courts between 1972 and 2004, the majority of which were initiated in the 1970s and 1980s.25 Although the study identified a peak in the judicial activity in 1999, it was suggested that this may have been owed to the enactment of the UK's 1998 Competition Act, ${ }^{26}$ and not to the Commission's purported "push" for private EU antitrust claims. ${ }^{27}$ Several factors were identified as possible causes for the limited take up of private litigation in this area, such as the lack of uniform rules governing the proof of individual infringements, the difficulties associated with locating and proffering evidence of unlawful practices, including the limits placed on the courts' own power to require its production at trial in

21 Ibid., para. 18.

22 Ibid., paras 18-19. Also, see Commission White Paper on Modernisation of the rules implementing Articles 85 and 86 EC Treaty [now 101 and 102 TFEU], [1999] OJ C132/1 (hereinafter referred to as "1999 White Paper"), especially paras 6, 8-10; for commentary, see e.g. C.D. Ehlermann, "The modernization of EC competition policy: a legal and cultural revolution" (2000) 37 CML Rev 537, pp. 550-551; cf. Wesseling, "The draft regulation modernising the competition rules: the Commission is married to one idea" (2001) 26(4) EL Rev 357.

23 See e.g. Shaw, "Competition complainants: a comprehensive system of remedies?" (1993) 18 ELRev 427, pp. 440-441; but cf. Paulweber, "The end of a success story? The European Commission's White Paper on the Modernisation of EC Competition Law" (2000) 23 World Competition 3, pp. 7-9; see also 1999 White Paper, paras 24-25; for commentary, see, inter alia, Venit, "Brave new world: the modernisation and decentralisation of the enforcement under Articles 81 and 82 of the EC Treaty" (2003) 40 CML Rev 545, especially pp. 550-552; cf. Riley, "EC antitrust modernization: the Commission does very nicely, thank you! Part 1: the Commission and the notification burden" (2003) 24(11) ECLR 604, see especially pp.609-611.

24 Rodger, "Competition law litigation in the UK" (2006) 27(5) European Competition Law Review 235; (2006) 27(6) European Competition Law Review 279; (2006) 27(7) European Competition Law Review 341.

25 Ibid., part I, p. 241.

26 Ibid., p. 245.

27 Ibid.; see also p. 246. 
several Member States and the lack of binding legal effects for administrative decisions finding a breach before the domestic courts. ${ }^{28}$ However, throughout the 1990s it was the lack of an express cause of action to claim compensation for competition damages that emerged as perhaps the most significant hurdle standing in the way of these lawsuits. ${ }^{29}$

In this respect, it is noteworthy that strong arguments in favour of recognizing a similar remedy had been made on the basis of the Francovich judgment. ${ }^{30}$ Nonetheless, the inconsistencies arising from the application of the principle of national autonomy and the persistent doubts as to the suitability of domestic rights of actions to accommodate these claims prevented the development of competition damages actions. ${ }^{31}$ Consequently, the Crehan preliminary ruling ${ }^{32}$ was hailed as a real breakthrough in the affirmation of an EU-wide right to compensation for losses caused to plaintiffs as a consequence of an infringement of Articles 101 and 102 TFEU. As is well known, in that decision the Court of Justice recognized that the effet utile of Article 101 would be impaired if an individual could not rely on its infringement in order to obtain compensation for the damages he had suffered as a result of an anti-competitive agreement, ${ }^{33}$ subject to specific conditions designed in particular to prevent the unjust enrichment of the parties to an unlawful agreement or concerted practice. ${ }^{34}$ In the Court's view, this remedy served a twofold purpose, that is, to discourage future anti-competitive practices as well as to provide effective protection to the rights they sought to confer to the individuals concerned by their application. ${ }^{35}$

28 See e.g. 2004 Green Paper's Impact Assessment Document, paras 32-44; for commentary, see e.g. Riley, "EC antitrust modernization: the Commission does very nicely, thank you! Part 2: between the idea and the reality decentralisation under Regulation 1" (2003) 24(12) ECLR 657, pp. 666-668.

29 See, inter alia, Jones, Private Antitrust Enforcement in the EU, the UK and the US (1999, OUP), pp. 47ff.; see especially pp. 59-61; also see 2004 Green Paper's Impact Assessment Document, para. 17.

30 Joined cases C-6/90 and C-9/90, Francovich and others $v$ Italian Republic, [1991] ECR I-5357, especially paras 33-37 and 41-42; see e.g. Jones, op. cit. (fn. 29), pp. 70-78.

31 See e.g. Riley, op. cit. (fn. 23) at 667; also, inter alia, Steiner, "How to make an action suit the case: domestic remedies for breach of EEC law" (1987) 12 ELRev 102 at pp. 106-107.

32 Case C-453/99, Courage v Crehan, [2001] ECR I-6297.

33 Ibid., paras 19 and 23.

34 Ibid., paras 30-31.

35 Ibid., paras 26-27. 
In the later Manfredi preliminary ruling the Court broadened the standing conditions to claim competition damages to all individuals and legal entities who could establish that they had been harmed as a result of anti-competitive conduct, subject to establishing the existence of a "causal link" between the infringement of the EU competition rules and the damages the plaintiff had suffered. ${ }^{36}$ In that decision, the Court emphasized the link existing between the restoration of harm and the rationale of deterrence for competition damages ${ }^{37}$ and held that the victim of unlawful behaviour could claim compensation for the harm suffered and the lost profits, along with the payment of interest. ${ }^{38}$ As to the availability of "enhanced" or "punitive" damages, the ECJ emphasized that this remedy remained subject to the principle of national autonomy, according to which it would be for the domestic legal systems of each Member State to prescribe the conditions governing these actions, ${ }^{39}$ subject to the further caveats of equivalence and of practical possibility. ${ }^{40}$ In this specific respect, the Court held that "punitive" awards would not be required to secure the "effectiveness" of this remedy given its eminently restorative function. Nonetheless, it made clear that, should "special damages" be available for "similar claims", the domestic courts would have no choice but to award them to winning claimants. ${ }^{41}$

The enactment of Council Regulation No 1/2003 sought to boost the importance of EU competition lawsuits as a means of securing the efficacy of competition policy throughout the Union: as is well known, the Regulation conferred to national courts the power to apply Articles

36 Case 295/04, Manfredi v Lloyd Adriatico Assicurazioni SpA, [2006] ECR I-6619, paras 60-61; also case C-101/04, Cipolla v Fazari, [2006] ECR I-11421, paras 46-47.

37 See Manfredi, op. cit. (fn. 36), paras 62-64.

38 Ibid., paras 60-61; also case C-101/04, Cipolla v Fazari, [2006] ECR I-11421, paras 46-47; see also paras 62-64.

39 See case C-295/04, Manfredi, op. cit. (fn. 36), paras 60-61.

40 Manfredi, op. cit. (fn. 36), paras 62-64. See also Council Regulation No 1/2003 of 16 December 2002, see especially Recitals 3, 4 and 7 of the Preamble; 2008 White Paper, paras 99-100. For commentary, see, inter alia, Komninos, "New prospects for private enforcement of EC Competition law: Courage $v$ Crehan and the Community right to damages" (2002) 39 CML Rev 447. Commission Impact Assessment Document, SEC (2008) 404, para. 74; see also para. 81; more recently, see 2011 Consultation document, para. 17. For comment, see e.g. Milutinovic, "Private enforcement: upcoming issues" in Amato and Ehlermann (eds), EC Competition Law: A Critical Assessment (2007, Oxford: Hart), 727, especially pp. 751-756.

41 Manfredi, op. cit. (fn. 36), paras 92-93. 
101 and 102 in their entirety to private disputes; it also laid down mechanisms of "soft" cooperation between the Commission and the national courts. ${ }^{42}$ However, as was anticipated, ten years since the enactment of Regulation 1 the take up of new private antitrust actions has remained noticeably lower than expected, at least in some Member States. In 2004 the Ashurst Report, commissioned by the European Commission to examine the state of private competition claims across the Member States, went as far as to describe the situation as one of "astonishing diversity [...] and total underdevelopment". ${ }^{43}$ The data concerning the extent of the private competition litigation in the UK until 2007 seem to confirm this finding: in that jurisdiction, the number of fresh lawsuits was markedly higher in the 1970s and 1980s and reached its peak around 1999, just after the enactment of the UK Competition Act of 1998. 44 However, as Rodger noted, no similar "peak" was registered after the entry into force of the Modernisation Regulation, as the Commission had envisaged. ${ }^{45}$

These figures seem to reflect a broader trend across the EU, where only 60 private competition cases had been lodged up to $2004,{ }^{46}$ after which only a marginal improvement was registered: the Commission's External Impact Assessment document accompanying the 2008 White Paper noted that 96 further cases had been initiated between 2004 and the first trimester of 2007. ${ }^{47}$ More recent research conducted since 2009 in the United Kingdom, however, seems to signal a partial "awakening" of competition claims. The study conducted by Rodger, spanning the years between 2009 and 2012, found that 106 judgments concerning the application of domestic and EU competition rules had been handed down in 80 different disputes: of these, 44 led to judgments within the same time frame. ${ }^{48}$

42 See 2008 White Paper, paras 99-100. For commentary, see, inter alia, Komninos, "New prospects for private enforcement of EC Competition law: Courage v Crehan and the Community right to damages" (2002) 39 CML Rev 447.

43 See Ashurst Report, Comparative Report, para 1.

44 Rodger, "Competition law litigation in the UK" (2006) 27(5) European Competition Law Review 235 at 241-242.

45 Ibid., p. 244.

462004 Ashurst Report, Comparative Report, para. 1.

47 See External Impact Assessment Report, available at: http://ec.europa.eu/ competition/antitrust/actionsdamages/files_white_paper/impact_study.pdf, para. 1.2.1, p. 39 .

48 Rodger, "Competition law litigation in the UK courts: a study of all cases" (2013) 6(2) GCLR 55 at 56-57. 
Rodger observed that, if seen against the background of case law between 1999 and 2009, an upward trend could clearly be detected. The study also pointed out that in a number of cases the parties had reached a settlement out of court. ${ }^{49}$ As to the nature of the lawsuits, the study found that about a third of the judgments given in the three years between 2009 and 2012 had been the result of stand-alone actions lodged with the High Court, with the remaining two-thirds being follow-on lawsuits decided by the Competition Appeals Tribunal (CAT). ${ }^{50}$ Consequently, the study seemed to confirm the increasing importance of follow-on litigation within the British jurisdiction as a means of facilitating access to justice for prima facie competition victims. ${ }^{51}$ However, it also emphasized that given its still limited take-up, much could still be done for strengthening the powers of the CAT and, more generally, for boosting the awareness surrounding these remedies among potential claimants. ${ }^{52}$ On this specific point, the circumstance that numerous claims had been settled out of court, while reiterating the continuing importance of non-judicial resolution mechanisms in these cases does not allow for a full consideration of the extent to which these remedies can provide appropriate relief for the injuries suffered by the victims of anti-competitive behaviour. ${ }^{53}$

The trends identified by Rodger in the UK may be usefully compared with those emerging from Germany. A recent study, conducted by Peyer and published in 2010, showed that in Germany 368 new cases had been lodged between 2005 and 2007: whereas 180 were terminated at first instance, 188 proceeded to appeal. ${ }^{54}$ Importantly, these new actions were predominantly aimed at seeking a declaration of nullity of allegedly anti-competitive agreements, with damages actions being a minority. .5 Peyer's study sought to analyse these figures against the wider background of the changing German judicial landscape: ${ }^{56}$ it was emphasized that a number of measures had been introduced between 2004 and 2008, with a view to boosting new claims: these measures ranged from more

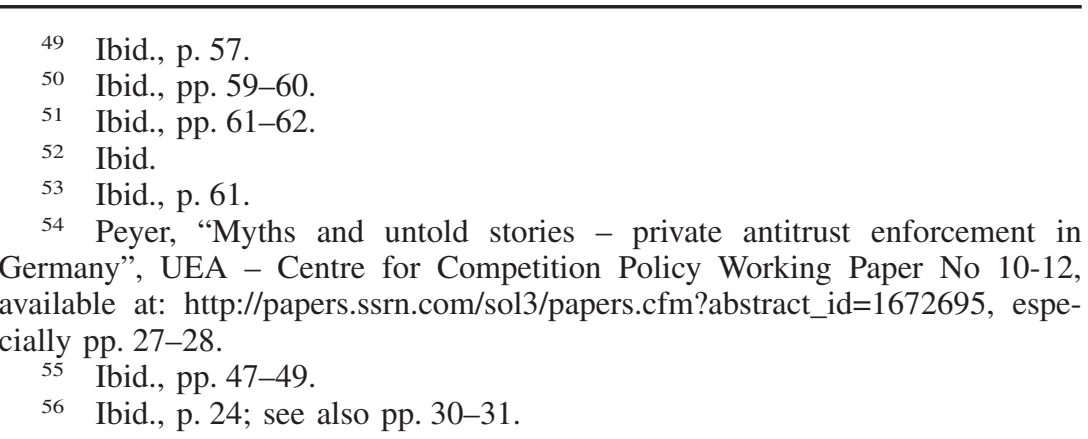


generous standing conditions to the recognition of binding force for administrative decisions finding individual infringements in follow-on cases. ${ }^{57}$

In light of these findings, it was argued that in Germany private competition litigation seemed to have been evolving towards becoming a complementary instrument to public enforcement. ${ }^{58}$ Nonetheless, Peyer also cautioned against "generalizing" the outcome of the German experience to the whole of the EU: it was suggested that the relatively low litigation costs, compared with other Member States, together with a culture which sees the courts as the "natural forum" for individuals" grievances, may have led to an overall cautious growth of competition litigation in Germany. ${ }^{59}$ More generally, it is undeniable that this study has questioned the almost total identification of private competition litigation with judicial proceedings lodged for the purpose of obtaining compensation for damages arising from anti-competitive behaviour: ${ }^{60}$ on this point, it was queried whether the continuing emphasis on tort cases in the area may have overshadowed other remedies, such as actions for the declaration of nullity of anti-competitive agreements, which may have been just as effective in restoring the victims' interests. ${ }^{61}$

Against this background, it is argued more generally that the discussion on promoting enforcement of the competition rules seems to have been gradually broadened to encompass not just damages claims but a wider array of tools encompassing action or the annulment of contracts and for the granting of injunctive relief. ${ }^{62}$ In addition, the brief discussion of the UK experience since 2009 seems to show that reliance on the findings of the national competition agencies and of the EU Commission's earlier decisions in follow-on actions is becoming increasingly important for individual claimants wishing to access the courts to obtain relief of their prima facie competition injuries. ${ }^{63}$ Overall, it may be concluded that recent years have seen competition litigation gaining some

57 Ibid., p. 32; see also pp. 36-37.

58 Ibid., pp. 38-39.

59 Ibid., p. 66.

60 Ibid., pp. 67-68.

61 Ibid., p. 69.

62 Ibid.; see also Buxbaum, "German legal culture and the globalisation of competition law: a historical perspective on the expansion of private antitrust enforcement", Indiana University Law School - Bloomington Research Paper No 22/2005, available at: http://papers.ssrn.com/sol3/papers.cfm?abstract_id= 716362, pp. 111-112, 114-116.

63 See, inter alia, Rodger, op. cit. (fn. 48), pp. 60-61. 
momentum in certain European jurisdictions: however, it is undeniable that these improvements remain patchy, being limited only to a restricted number of jurisdictions. ${ }^{64}$ In addition, it may queried whether concentrating the discussion almost exclusively on the competition damages' remedy may only allow for a "partial" response to emerge to the question of how to identify "suitable" remedies for the need of competition injuries. Perhaps more importantly, it is submitted that how to deal with the "diffuse" consequences of anti-competitive practices is a crucial question in this wider discussion, which will be among those issues that will be examined in later sections.

\subsection{Boosting the "Underdeveloped" Private Antitrust Litigation in the EU: from the 2004 Green Paper on Antitrust Damages to the 2011 Consultation on Collective Redress}

The previous section attempted to give a snapshot of the development of the right to compensation for antitrust damages in EU law and highlighted the ongoing concern, expressed by many quarters, about the paucity of these actions. This section will seek to gauge the key issues that have been identified as the root cause of the status quo and in that context will identify the role envisaged for collective redress mechanisms. In its 2005 Green Paper65 DG Competition identified a number of possible causes for the near-total absence of these actions (at least at the time): the existence of an information asymmetry between the defendant, who was in a position of controlling much of the evidence required to prove the existence of an infringement, and the plaintiff; the complexity of these cases; and the costs associated with bringing specific actions, especially when balanced against both the perspective of success and the amount of compensation likely to be awarded to an individual claimant. ${ }^{66}$

As a result, the Green Paper argued in favour of creating "incentives" to readjust this "risk-reward balance" more in support of plaintiffs, ${ }^{67}$ by correcting the perceived information asymmetry, especially in respect to

64 Ibid., p. 40-41.

65 Commission Green Paper - Damages actions for breach of the EC antitrust rules, $\operatorname{COM}(2005) 0672$ Final, SEC (2005) 1732, hereinafter referred to as the "2005 Green Paper".

66 See Ashurst Comparative Report, paras 61-62, 92, 94-95; also Commission Staff Working Paper, Annex to the Green Paper, COM/2005/0672, final (hereinafter referred to as "the 2005 Staff Working Paper"), paras 32-36; see also paras 103, 109-112, 203 and 213-214.

67 See 2005 Staff Working Paper, para. 45. 
the access to and the availability of evidence and by taking action as regards the burden of proof of infringements and the litigation and legal representation costs. ${ }^{68}$ Of particular concern to the Commission was the availability of redress against the consequences of anti-competitive behaviour for consumers and small businesses: it was argued that recourse to the domestic courts on the part of these claimants on their own would be "unlikely" for the small size of the amount claimed, especially when viewed against the economic commitment associated with bringing an individual action and the difficulties linked to proving an infringement and the resulting loss. ${ }^{69}$

For this reason, the Staff Working Paper, inspired also by legislation introduced in, inter alia, Sweden and the United Kingdom, suggested, alongside other measures such as the provision for small claim procedures, the introduction of collective actions as a means to claim damages arising from anti-competitive behaviour: ${ }^{70}$ it was argued that consumers, even in large numbers, who suffer only small losses individually are "almost certainly" discouraged from having recourse by the costs, delays and difficulties that these actions entail. ${ }^{71}$ Consequently, it was suggested that "consolidating a potentially large number [of claims] into one" claim would reduce the costs associated with bringing repetitive claims and thus improve the efficiency of the machinery of justice. ${ }^{72}$ It would avoid the drawbacks of "tactical litigation", that is, of mainly duplicated litigation whose outcome tends to be biased against the defendant, due to the asymmetry in information and economic power existing vis-à-vis the claimant. ${ }^{73}$

In this specific respect, the Staff Working Paper sought to distinguish between "representative actions", that is, those brought by consumer associations or other collective bodies in defence of the interests of their own members, "representative actions", namely lawsuits lodged by a

68 Ibid., para. 109-112, 203 and 213. For commentary, see e.g. Eilmansberger, "The Green Paper on damages action for breach of the EC anti-trust rules and beyond: reflections on the utility and feasibility of stimulating private enforcement through legislative action" (2007) 44 CML Rev 431, especially pp. 455-457.

69 See 2005 Green Paper, para. 2.5; also 2005 Staff Working Paper, para. 195-198.

702005 Staff Working Paper, para. 193.

71 Ibid., para. 188.

72 Ibid., paras 192-193.

73 Ibid. See e.g. Rosenberg, "The regulatory advantage of class actions", in Viscusi (ed.), Regulation Through Litigation (2002, Washington, DC: AEI Brookings Institution Press), pp. 271ff. 
claimant on behalf of a "group of identified or identifiable individuals to protect the interests of those represented" and "public interest suits", introduced for the benefit of the public and not designed to represent anyone in particular. ${ }^{74}$ As was anticipated, none of these remedies is or, indeed, was in 2005, a novelty: in this respect, the Staff Working Paper drew a parallel between the second type of collective actions it enumerates and the representative lawsuit that could be brought on behalf of a group under Swedish legislation. ${ }^{75}$ As to the latter type, it is noteworthy that in Denmark the Consumer Ombudsman enjoys the right to bring actions in the public interest to redress large, diffuse torts. ${ }^{76}$ The format of "representative action" brought by collective organizations, instead closely resembled the action provided by the UK Competition Act $1998 .{ }^{77}$

Collective actions were regarded by the Commission as being particularly well suited to deal with the challenges posed by the attainment of the twin goals of compensation and deterrence of future anti-competitive behaviour. 78 It was argued that without some "aggregation" mechanism victims of antitrust infringements such as consumers and small businesses would be left without a remedy due to the costs, difficulties and the uncertainties involved in this type of litigation. ${ }^{79}$ The White Paper therefore proposed the introduction of two forms of collective redress, namely "representative actions" brought by collective bodies and collective actions in the form of "opt in" lawsuits, in which individual claimants

742005 Staff Working Paper, para. 192.

75 Ibid., para. 194. See e.g. Cafaggi, "The great transformation. Administrative and judicial enforcement in consumer protection: a remedial perspective" (2009) 21 Ly Cons L Rev 496 at 505-506; see also Stuyck, "Class actions in Europe? To opt in or opt out, that is the question" (2009) 20(4) EBLRev 483, especially pp. $485 \mathrm{ff}$.

76 See 2009 (Consolidation) Danish Marketing Practices Act, Section 20(1). For commentary, see e.g. Mulheron, "The case for an opt-out class action for European Union Member States: a legal and empirical analysis" (2009) 15 Colum J Eur L 409 at 438; also, mutatis mutandis, Hodges, "Collective redress in Europe: the new model" (2010) 29(3) CJQ 370 at 392-393.

77 UK Competition Act 1998, sections 47A and 47B.

782005 Staff Working Paper, para. 193; see also para. 194. For commentary, inter alia, Rosenberg, op. cit. (fn. 73), pp. 272-274; also, more generally, Hensler et al., Class Actions Dilemmas (2000, Santa Monica, CA: RAND Institute), pp. 407-410.

79 Commission White Paper on Damages actions for breach of the EC antitrust rules, $\operatorname{COM}(2008) 165$ (hereinafter referred to as the "2008 White Paper"), text to fn. 6 and 7. 
decide actively to "add" their claim to a collective suit. ${ }^{80}$ According to the Commission's Impact Assessment Document accompanying the White Paper, these actions would balance the need to grant effective access to justice to the "diffuse" victims of anti-competitive behaviour against both the efficient administration of justice and the need to protect the effectiveness of public enforcement, especially against "frivolous" litigation. $^{81}$

However, it is apparent from the White Paper that the Commission was wary of proposing the introduction of "opt-out" collective actions, along the lines of the action provided in Rule 23 of the US Federal Courts Rules of Procedure. As is well known, these actions can be brought on behalf of unidentified persons that have been similarly affected by the allegedly wrongful actions of the same defendant and have not sought to exclude themselves from the scope of the litigation by "opting out" of it in time after the court seized with the complaint adopted a decision "certifying the class", that is, allowing the litigation to proceed in the name of the class representative and on behalf of all. ${ }^{82}$ The Impact Assessment Document stated that these actions would be likely to lead to the "over-compensation" of antitrust damages and could even jeopardize key aspects of public enforcement, such as the effectiveness of leniency programmes. ${ }^{83}$ Also, due to the potentially vast number of plaintiffs, they could result in an increase of litigation costs and of error costs, ${ }^{84}$ engender "excesses" and cause individual class members to "lose control" of the lawsuit, to the detriment of their effective legal representation. ${ }^{85}$ By contrast, opt-in actions and lawsuits lodged by collective

80 Ibid

81 Commission Impact Assessment Document, SEC (2008) 404, para. 74; see also para. 81. For comment, see e.g. Milutinovic, "Private enforcement: upcoming issues" in Amato and Ehlermann (eds), EC Competition Law: A Critical Assessment (2007, Oxford: Hart), 727, especially pp. 751-756.

82 See, inter alia, Leskinen, "Collective antitrust damages in the EU: the opt-in versus the opt-out model", IE Law School Working Paper No 10-03, available at: http://papers.ssrn.com/sol3/papers.cfm?abstract_id=1612731, pp. 4-5.

83 See e.g. 2008 Impact Assessment Document attached to the 2008 White Paper, para. 119.

84 Ibid. For commentary, see e.g. Russell, "Exporting class actions to the European Union" (2010) 28 Boston Uni. Int'l L J 141, especially pp. $152 \mathrm{ff}$.

85 White Paper, Commission Working Document SEC(2008) 404 (hereinafter referred to as "the 2008 Working Document"), para. 58. 
bodies would be more consistent with the pattern of "traditional litigation" and therefore more predictable, and overall more "acceptable" to national legislatures and courts. ${ }^{86}$

The 2008 White Paper was supported by a number of institutional stakeholders: the European Parliament, for instance, expressed the view in its 2009 resolution that these actions could effectively complement other tools for the efficient application of the Treaty competition rules. ${ }^{87}$ In this context the Parliament also identified mechanisms for the "collective redress" of competition injuries as a useful auxiliary tool vis-à-vis instruments that were already generally available in the laws of several Member States, such as forms of alternative dispute resolution (ADR), test cases and representative actions. ${ }^{88}$ However, the same Resolution remained very sceptical of the Commission's "case for action" on the ground that the former had not identified a suitable legal basis for adopting measures in this area; nor had it provided a justification as to whether Union intervention complied with principles of subsidiarity and of proportionality. ${ }^{89}$

Perhaps more importantly, the European Parliament made a forceful call in favour of moving away from a "sector-specific" approach to these proposals for reform and, instead, urged the Commission to concentrate its efforts on bringing about proposals for a "horizontal approach" to collective redress. ${ }^{90}$ These proposed measures should be applicable to all claims originated from "dispersed and [individually] low-value" injuries and should especially aim at granting an efficient avenue for the relied of injuries which would otherwise go uncompensated. ${ }^{91}$ On that basis the European Parliament cautioned against seeking to adopt "sector specific" measures in the area of group litigation and more generally of collective redress: it took the view that many of the perceived "difficulties" concerning the bringing of competition claims were not unique to these cases but characterized a significant number of torts, ranging from product liability claims to environmental damages actions. ${ }^{92}$ In the Parliament's opinion, "dispersed and relatively low value damages,

\footnotetext{
86 Ibid

872009 European Parliament Resolution, op. cit. (fn. 6), Preamble, Recitals

88 Ibid., Preamble, Recitals C and E.

89 Ibid., para. 2.

90 Ibid., para. 3.

91 Ibid., para. 5.

92 Ibid., paras 5-6.
} $\mathrm{C}$ and $\mathrm{H}$. 
information asymmetries [...] [and] costs, delays and uncertainties" were not exclusive of competition claims. ${ }^{93}$

Thus, the 2009 Resolution urged the Commission to engage in a more open-minded and, perhaps more importantly, legally principled discussion of whether the enactment of common measures affecting the domestic rules on collective litigation and seeking to encourage competition lawsuits complied with the general principles of conferral, subsidiarity and proportionality. ${ }^{94}$ On this point it was emphasized that unless these general questions could be addressed any proposal for the "special treatment" of competition cases would probably be met with scepticism, if not with outright rejection. ${ }^{95}$

In light of these sobering words, it was not surprising that an informal proposal drafted in 2009 and "leaked" just before the drafting of the Work Programme for the following years did not make it into the Commission agenda for 2010.96 Instead, the Commission, now mindful of the lack of support for the proposal for a competition class action, opted for a new consultation, this time aimed at exploring options for the collective redress of all "diffuse injuries". In the 2011 Joint Information Note on Collective Redress ${ }^{97}$ the Commission not only proposed the introduction of a generally applicable framework for facilitating the litigation via representation of diffuse tort disputes; it also sought views on the possibility of introducing a common set of tools, whether judicial or non-judicial, "that may accomplish the cessation or prevention of unlawful business practices which affect a multitude of claimants or the compensation for the harm caused" thereby. ${ }^{98}$ As for the question of how the "judicial mechanisms" should be structured, the Joint Information Note envisaged the introduction of opt-in and representative actions. ${ }^{99}$ Just as it had done with competition claims, the Commission emphasized that seeking to adopt any more "claimant-friendly" forms of action, such as the "US-style" opt-out class action, or to introduce "incentives to sue" (including, among others, contingency fee agreements) would have

\footnotetext{
93 Ibid., paras 3-4.

94 See ibid., paras 13-15; see also paras 18-21.

95 Ibid.

96 See, inter alia, Rizzuto, "The private enforcement of EC competition law: what next?" (2010) 3(2) GCLR 57 at 59-60.

972011 Joint Information Note, op. cit. (fn. 7), see especially paras 9, 20-22.

98 Ibid., para. 7.

99 Ibid.
} 
engendered abusive litigation as well as being, more generally, inconsistent with the principles guiding civil litigation in the Member States. ${ }^{100}$

Following a period of consultation the Commission enacted a measure designed to "harmonize" the key principles guiding collective redress of "diffuse" injuries across the Union. However, it did so by relying on a non-binding act, namely a Recommendation, addressed to the Member States and seeking to engender gradual convergence around a set of common principles, guiding both group litigation and non-judicial mechanisms for the resolution of disputes arising from "mass harm situations". ${ }^{101}$ Once again the Commission rejected calls for discussing a wider range of options than those envisaged in the Joint Information Note, and confined to the role of "exceptions" other more generous forms of action or mechanisms for encouraging future claims. ${ }^{102}$

It is therefore clear that after the 2008 White Paper and the unsuccessful attempt to table a proposal for legislation in 2009 the Commission sought to separate neatly its attempt to adopt measures designed to facilitate competition litigation, by means of binding common rules, from action generally aimed at facilitating the collective redress of mass torts. Having regard more specifically to the former, it should be emphasized that 2013 also saw the EU Commission tabling a Draft Directive designed to ease access to the courts for the victims of anti-competitive behaviour; 103 however, not surprisingly, no mention was made of collective litigation, a matter now securely confined, it may be argued in light of the 2013 Recommendation, to "horizontally applicable" soft law. ${ }^{104}$

Against this background a question emerges as to the extent to which the Commission's new approach, which appears to rely on a combination of legally binding measures, drafted to address substantive issues arising from claims in certain areas of EU law and "soft" rules designed to encourage convergence around common principles, so that eventually the

100 Ibid., para. 20; see also 2008 White Paper, para. 21.

101 Commission Recommendation of 11 June 2013 on common principles for injunctive and compensatory collective redress mechanisms in the Member States concerning violations of rights granted under Union Law, [2013] OJ L201/60 (hereinafter referred to as the "2013 Recommendation"); see especially section III.1; see also Preamble, Recital 9.

102 Ibid., para. V.22.

103 European Commission, Proposal for a Directive of the European Parliament and of the Council on certain rules governing actions for damages under national law for infringements of the competition law provisions of the Member States and of the European Union, SEC(2013) 404 final, available at: http://eurlex.europa.eu/LexUriServ/LexUriServ.do?uri=COM:2013:0404:FIN:EN:PDF.

104 See infra, Chapter 7, sections 2.2 and 3.2. 
former can be lodged according to more and more mutually consistent rules, represents an appropriate response to the long-standing question of how to boost the take-up of competition claims as lawsuits arising from "mass harm situations". The purpose of this work will be to address this broad question. The remainder of this chapter will consider some of the theoretical rationales behind collective actions aimed at achieving goals that are common to large groups of individuals - in general as well as in the field of civil litigation. Thereafter, Part II will examine the rules and approaches governing class certification in antitrust damages claims in the US federal jurisdiction. In this context, it will be argued that the US higher courts have, over time, shaped the certification inquiry into a sharp instrument designed to select only those cases that are "well-suited" to class litigation on the basis of a careful assessment of both the claim and of the proof proffered by the named plaintiff, so as to avoid "frivolous" cases and secure the efficient administration of justice. In this part of the work it will also be illustrated that the "case management" powers enjoyed by the courts both at the onset and in the course of the trial can effectively countervail the risk that class counsel may collude with the defendant so as to maximize her return and damage the class interests.

Thereafter the analysis will turn to the examination of the state of play as regards collective redress and group litigation within the EU today. It will be argued that the "landscape" in which the debate in this area had originated at Union level has now dramatically changed, due to the increasing activity of domestic legislatures in these areas. Chapters 5 and 6 will examine the legislation already in force or still contemplated in a number of jurisdictions, and on that basis it will highlight that a significant degree of "experimentation", often far from the EU Commission's "preferred models" for group litigation seems already to have taken place. Thus, it will be argued that the current approach prevailing at Union level, and especially the justifications offered for it, seems less and less sustainable. On this basis, it will be suggested that unless the Commission is at least willing to contemplate the possibility of allowing limited, more generous forms of collective litigation, such as, among others, a "guarded" opt-out action, its "preferred" approach, enshrined in the 2013 Recommendation, is unlikely to complement effectively otherwise promising binding measures designed to facilitate competition litigation.

Chapter 7 will highlight the fact that the European Parliament, in the run up to the adoption of the 2013 Recommendation, had expressly invited the Commission to consider adopting "specific" rules designed to adapt its horizontal approach to collective redress to the demands of litigation in this field; on that basis, it will be argued that the reliance on 
the sound administration of justice as a ground to justify exceptions to the solution championed in the Recommendation could allow the latter to be adapted in the domestic jurisdiction and thereby take a different and more generous form that could secure greater access to justice and thereby respond more effectively to the demands of competition litigation. To this end, the final chapter, without advocating in favour of the full transplantation of class actions, modelled against the US Federal Rules of Procedure, will argue that a "limited opt-out", subject to strict admissibility criteria and assisted by strong supervisory powers, vested with the court, could strike a fair balance between the need to maintain appropriate standards of "due process" for all parties and meeting the demands of adjudication efficiency in complex and otherwise "repetitive" cases. In this specific respect, it will be emphasized that providing fuller access to justice for the victims of injuries, whose origin lay in infringements of "public interest" rules, among which competition law features prominently, would also serve the broader goal of strengthening the overall enforcement of these rules not just via the imposition of sanctions but also through the achievement of the restoration of the interests of those affected by "diffuse" and often uncompensated torts.

\section{PART II ENHANCING THE PRIVATE ENFORCEMENT OF THE COMPETITION RULES IN THE EU: WHY COLLECTIVE ACTIONS?}

\section{INTRODUCTORY REMARKS}

\subsection{Genuine Competition as a "Public Good": Identifying the Theoretical Underpinning for Collective Litigation in Private Antitrust Enforcement}

The previous sections briefly discussed the trends characterizing the debate on private competition enforcement in the EU. It was illustrated that, despite numerous efforts, the EU Commission only succeeded in tabling a concrete proposal aimed at facilitating these actions in domestic courts in 2013. Although, as will be illustrated in greater detail in Chapter 7, the Draft Directive is promising and rather ambitious on key issues, including consumer standing and the coordination of public and private enforcement, it remains silent on any future measures designed to increase access to justice for competition claimants via the medium of collective redress and, in that context, of collective litigation. Against this 
background it will be questioned whether the combination of the proposed binding rules with "soft law" measures, such as the 2013 Recommendation on Collective Redress, which is horizontally applicable to all mass harm cases, can reinforce the rights of competition injury victims by ensuring that over time a "common core of principles" governing group access to the courts in these cases is embedded in the laws of the Member States.

The remainder of this chapter will seek to examine the main theoretical justification for the need of effective and "suitably designed" forms of collective adjudication and, more generally, of "group resolution" of disputes arising from the widespread impact of anti-competitive practices. It was illustrated in section 1.2 above that according to the Court of Justice of the EU a clear connection existed between the rights of the victims of "competition injuries" to seek compensation for the loss they had suffered and the concern for the effective enforcement of the Treaty competition rules. ${ }^{105}$ Seen in this light, competition litigation plays an auxiliary role vis-à-vis public enforcement since it aims to secure the effet utile of Articles 101 and 102 TFEU through the restoration of harm caused by unlawful arrangements and practices. However, lodging these claims has proven problematic for a number of reasons: already in Manfredi, the Court of Justice acknowledged the "covert" nature of competition infringements, as a result of which their victims would often be unable not only to gather relevant evidence but also to gauge the existence and the extent of the injury they had suffered. ${ }^{106}$ In addition, it was often observed that since they had a "diffuse" impact on society and the economy, antitrust injuries resulted in individual claims only being able to lodge a lawsuit of low unitary value. ${ }^{107}$

Thus, especially when the size of the claim was seen against the background of complex and costly cases whose outcome was difficult to assess, it was not surprising that potential plaintiffs would often not even attempt to "go to court": in other words, individual actions having a very small, if not altogether a "nominal" value were regarded as not being

105 Case C-453/99, Courage, op. cit. (fn. 1), para. 26; see also case C-295/04, Manfredi v Lloyd Adriatico Assicurazioni SpA, [2006] ECR I-6619, paras 60-61, see also para. 91.

106 Case C-295/04, Manfredi, op. cit. (fn. 36), paras 88-89.

107 Ibid.; see also 2008 White Paper, para. 1.2. 
"worth the effort" of having to initiate uncertain, difficult or expensive legal proceedings. ${ }^{108}$

Consequently, collective redress mechanisms including, but not limited to, collective litigation, have emerged in a number of jurisdictions as a means of fulfilling the demands posed by having to grant access to justice to the victims of these often "secret" and complex torts. It was often argued that group lawsuits represent a "statute made" mechanism designed to spread the often sizeable costs associated with individual proceedings across a wider spectrum of claimants, thus making the value of their claims "worthier" of pursuit. ${ }^{109}$ In addition, by securing justice for the consequences of those prima facie infringements that may have slipped through the net of public enforcement, collective litigation has proven effective in boosting the effectiveness of the overall application of the competition rules. ${ }^{110}$

As is well known, the US federal legal system has relied heavily on class actions as a means to securing compensation and deterrence in the field of antitrust law: in Hawaii v Standard Oil, the US Supreme Court held that allowing these claims to proceed collectively enhanced "the efficacy of private actions, by permitting citizens to combine their limited resources and to achieve a more powerful litigation posture". ${ }^{111}$ This "enhanced" position would, in turn, facilitate the aggrieved individuals in obtaining compensation for their injuries. ${ }^{112}$

These questions will be expounded in more detail in later chapters. Nonetheless, it is indispensable to note at this junction that the US Federal Courts have consistently endorsed the US Supreme Court's view, expressed in the Standard Oil decision, that antitrust damages claims, if lodged by or on behalf of a plurality of would-be claimants, could be

108 See, inter alia, 2008 White Paper, text to fnn. 6 and 7; see also Areeda and Hovenkamp, Antitrust Law (2007, Frederick, MD: Aspen Publishers), pp. 47ff., especially pp. 48-49.

109 Benston, "A comprehensive analysis of the determinants of private antitrust litigation, with particular emphasis on class action suit and the rule of joint and several damages", in L.J. White (ed.), Private Antitrust Litigation: New Evidence, New Learning (1988, Cambridge, MA: MIT Press), p. 271.

110 See, inter alia, 2008 Commission Staff Working Paper, paras 19-21; also, mutatis mutandis, Rosenberg, op. cit. (fn. 73), pp. 245-246.

111 Hawaii v Standard Oil Co, 405 US 251 (1972), p. 266. See also Newberg and Conte, Newberg on Class Actions, 4th edn (Trial Practice Series, Thomson Reuters) (hereinafter referred to as "Newberg"), para. 18.01.

112 See, inter alia, Lang, "Class actions and the US antitrust laws: prerequisites and interdependencies of the implementation of a procedural device for the aggregation of low value claims" (2001) 24 W Comp 285 at 287-288. 
particularly "well-suited" to being litigated via representation. It was often held that in competition cases the "gist" of an individual claim, namely "the alleged damage arising from the allegedly wrongful act" committed by one defendant to the detriment of a large section of society, would remain the same, regardless of whether the actual size of the damage suffered by individual would-be claimants varied across the group represented in litigation. ${ }^{113}$ Thus, for example, in relation to price-fixing claims, the court deciding on the admissibility as class action of a collective antitrust complaint would normally allow it to proceed if, since "the gravamen of [the] claim [...] [was shown to be] that the price in a given market [had been] artificially high", it would be reasonable to infer that all purchasers had been affected by the practice in a similar way, even though the size of the amount being sought could vary. ${ }^{114}$ So long as the named plaintiff could show that each element of the alleged antitrust offence was amenable to proof common to the class, ${ }^{115}$ certification would be regarded as appropriate and therefore collective litigation would be compatible with principles of due process and of efficiency in adjudication. ${ }^{116}$

As was aptly explained by the District Court of Alabama in Coleman $v$ Cannon Oil, class litigation allows the "consuming public" to vindicate their rights via the "most fair and efficient means of enforcing" the competition rules, especially when suing the defendant individually would not be "economically rational". 117 It is acknowledged that a number of studies have recently questioned the effectiveness of class litigation as a means of strengthening not just the compensation but also the deterrence function of the US antitrust rules. Elzinga and Breit, among others, doubted that, due to their complexity and the ensuing litigation costs, the private enforcement of antitrust rules via the medium of collective litigation delivered sufficiently significant benefits for claimants. ${ }^{118}$ It was also argued that class litigation and in particular the nature of the certification inquiry could increase these costs and thereby

113 Weeks v Bareco Oil Co, 125 F2d 84 (1941) at 91.

114 In Re: Potash Antitrust Litigation, 159 FRD 682 at 695-696; also in Re:

Foundry Resins Antitrust Litigation, 242 FRD 393 at 409.

115 See e.g. Re: Potash, op. cit. (fn. 114) at 696.

116 For commentary, see Newberg, para. 18.25.

117 Coleman v Cannon Oil, 141 FRD 516 (MD Ala, 1992), at 520.

118 Elzinga and Breit, The Antitrust Penalties: a Study in Law and Economics

(1976, New Haven, CT: Yale University Press), pp. 94-95. 
stifle, as opposed to encourage, access to justice for "dispersed" claimants. ${ }^{119}$ For these reasons, these commentators made a powerful argument for greater weight to be given to public enforcement as a more efficient and less costly mechanisms for the application of the Sherman Act. ${ }^{120}$

It is acknowledged that class litigation, especially when it concerns complex and fact intensive claims (as in the field of antitrust law), presents inevitable difficulties for litigants. However, it is argued that to limit access to justice to those affected by the consequences of anticompetitive behaviour in favour of an approach that relies almost totally on public enforcement would not be entirely consistent with the principle of "corrective justice", according to which "irrespective of the wealth of the respective parties, when one party engages in a form of wrongdoing which violates the equal autonomy of another party, a legal obligation is recognized to correct for the consequences of that wrongdoing". ${ }^{121}$ While it is beyond doubt that public enforcement plays a vital role in uncovering anti-competitive practices, it is submitted that this goal cannot be pursued at the expense of the objective of granting compensation to the victims of anti-competitive behaviour. ${ }^{122}$ Instead, it is argued that these two goals should be seen as mutually reinforcing. ${ }^{123}$

The need to uphold a strong and complementary relationship between public enforcement and private litigation in competition cases has been a key concern for the EU Court of Justice and the Commission. ${ }^{124}$ The EU Commission argued in its 2008 White Paper that the "restorative function" of competition claims would be effectively served by the introduction of strong mechanisms for the aggregation of "scattered", low value

119 Ibid., p. 93.

120 Ibid., p. 94.

121 Trebilcock and Roach, "Private enforcement of competition laws" (2004) 34 Osgoode Hall LJ 461, p. 496.

122 See Commission 2004 Green Paper on Antitrust Damages, SEC(2005) 1732, available at: http://eur-lex.europa.eu/LexUriServ/LexUriServ.do?uri=COM: 2005:0672:FIN:EN:HTML, para. 1.1. See also, inter alia, case C-295/04, Manfredi, op. cit. (fn. 36), paras 61-62.

123 Ibid.

124 See case C-295/04, Manfredi, op. cit. (fn. 36), paras 60-61 and 98; see also Commission Impact Assessment Document accompanying the 2008 White Paper, SEC (2008) 404, paras 192-194. For commentary, see e.g. J. Stuyck, "Class actions in Europe? To opt in or opt out, that is the question" (2009) 20(4) EBLRev 483, especially pp. 485ff.; see also 2008 White Paper, para. 1.2, fn. 5 and accompanying text. 
claims arising from the same allegations of anti-competitive behaviour: ${ }^{125}$ it was suggested that providing for the collective litigation of these lawsuits would improve the access to justice of the victims of restrictive practices and, by preventing the repetition of otherwise identical cases, would reduce the chances of "tactical litigation" by economically powerful defendants, thus improving the fairness of legal process. ${ }^{126}$

It should be emphasized that neither the EU Commission nor the Court of Justice accepted that "special incentives to sue", such as, inter alia, the provision for multiple damages, should have any place in this context. ${ }^{127}$ It is also noteworthy that the options available for discussion at Union level have been traditionally limited to opt-in and "ideological claimantled" actions, with opt-out lawsuits being seen as an "aberration" which had no place in European legal traditions, out of the same concern for confirming the "restorative nature" of competition damages across the EU. ${ }^{128}$ It is clear that even after the decided shift in favour of discussing "horizontal" proposals for collective redress reform and harmonization, this view has not changed: it is in fact apparent that competition litigation is envisaged as an important complement to the detection and sanctioning activities entrusted to competition agencies, a role which is in turn fully germane to its restorative function. ${ }^{129}$

Seen in this light, it is therefore argued that even in the absence of "special incentives to sue", facilitating the access to justice for individual victims through the "aggregation" of their claims that arise from the

125 Commission Impact Assessment Document, SEC (2008) 404, para. 74; see also para. 81; more recently, see 2011 Consultation Document, para. 17. For comment, see e.g. Milutinovic, "Private enforcement: upcoming issues" in Amato and Ehlermann (eds), EC Competition Law: A Critical Assessment (2007, Oxford: Hart), 727, especially pp. 751-756.

1262008 White Paper, text to fnn. 6 and 7.

127 Case C-295/04, Manfredi, op. cit. (fn. 36), paras 99-100; see also 2008 White Paper, paras 58-59. For commentary, see, inter alia, Denozza and Toffoletti, "Compensation function and deterrence effects of private actions for damages: the case of antitrust damages suits", March 2008, available at: http://papers.ssrn.com/sol3/papers.cfm?abstract_id=1116324, pp. 5-7, see also pp. 20-25.

128 Commission Impact Assessment Document, SEC (2008) 404, para. 74; see also para. 81; more recently, see 2011 Consultation Document, para. 17. For comment, see e.g. Milutinovic, "Private enforcement: upcoming issues", in Amato and Ehlermann (eds), EC Competition Law: A Critical Assessment (2007, Oxford: Hart) 727, especially pp. 751-756.

129 See e.g. 2004 Green Paper, para. 1; see also Denozza and Toffoletti, op. cit. (fn. 127), pp. 318ff. 
same alleged anti-competitive conduct would strengthen the effective application of the Treaty competition rules. ${ }^{130}$ It is in fact submitted that facilitating their collective resolution, either in court or through "alternative" mechanisms, would ensure that the losses caused to the plaintiffs do not go uncompensated and that, as a result, the tortfeasor is not "let off lightly" after a judicial finding that he or she infringed the competition rules. ${ }^{131}$ On this point, it is further suggested that although the EU view of competition damages as being merely "compensatory" in nature remains undoubted, this goal cannot be effectively attained unless litigation in this area is not "unduly costly" or excessively difficult to initiate and sustain. Granting litigants the possibility to access the courts via representation fulfils these objectives since it allows "disenfranchised" victims to obtain compensation by minimizing, if not altogether eliminating, the litigation costs and thereby creating the conditions in which "effective compensation" can be made available to individual would-be claimants in the event of successful civil proceedings. ${ }^{132}$

It should, however, be acknowledged that group litigation, due to its representative nature, constitutes a significant derogation to the principle of "personal autonomy" in the conduct of civil litigation: for this reason it was argued that a convincing justification, going beyond reasons of "expediency", should be found in order to support measures designed to boost its availability. It is submitted that the nature of competition cases seems to provide such a justification: it may be argued that recourse to collective litigation can not only lead to the sharing of often considerable litigation costs, which, if apportioned to each individual claim, would make litigation "uneconomical", 133 it would also be consistent with the nature of competition litigation as a means of reinforcing public interest goals and especially of attaining objectives of open and rivalrous markets, which represent "common goods" belonging to society as a

130 See e.g. Hawaii v Standard Oil Co, 405 US 251 (1972), p. 266. See also Newberg, para. 18.01; see also Case C-295/04, Manfredi, op. cit. (fn. 36), para. 61.

131 Manfredi, op. cit. (fn. 36); see also, inter alia, Lang, "Class actions and the US antitrust laws: prerequisites and interdependencies of the implementation of a procedural device for the aggregation of low value claims" (2001) $24 \mathrm{~W}$ Comp 285 at $287-296$.

132 See, inter alia, Mulheron, The Class Action in Common Law Legal Systems (2004, Oxford and Portland, OR: Hart Publishers), pp. 61-62; see also Lang, op. cit. (fn. 131), p. 286; also Issacharoff, "Group litigation of consumer claims: lessons from the US experience" (1999) 34 Tex Int'l L J 135 at 144-145.

133 See e.g., Rosenberg, "The regulatory advantage of class actions", in Viscusi (ed.), Regulation Through Litigation, op. cit. (fn. 73), pp. 271-272. 
whole. On this point, it was emphasized that since the pursuit of competitive markets is both an "indivisible" (namely, it can be enjoyed by one member of society without prejudicing the enjoyment of it on the part of others) and "non-excludable" (in the sense that it can be enjoyed by many individuals at the same time) good, ${ }^{134}$ it could be effectively pursued via collective action. It was further explained that reliance on collective litigation would also be broadly consistent with the "public interest" nature of the competition rules and with the recognized auxiliary nature of civil actions vis-à-vis the public enforcement activities entrusted with competition agencies. ${ }^{135}$

In light of the foregoing analysis it can be concluded that making available mechanisms for the group adjudication of otherwise individual "costly" and "complex" cases would contribute to greater access to justice, more effective and frequent restoration of antitrust harm and ultimately to the more efficient detection of competition infringements, provided that appropriate safeguards are in place to ensure the fair and efficient conduct of these proceedings. ${ }^{136}$ But how can a "group" of victims which is sufficiently homogenous as to make representative litigation a fair and efficient adjudication tool be identified? And how should these collective claims be designed in order to fulfil these very objectives? These questions will be addressed in the following sections.

\subsection{Identifying the "Group": the Role and Function of Standing Conditions}

Section 3.1 considered some general issues concerning the function of collective litigation in the context of private competition enforcement. It was argued that relying on forms of "collective justice" was both justified by and consistent with the "diffuse" nature of the harm arising from competition law breaches as well as with the "public interest" nature of competition enforcement generally. The purpose of this section will be to examine the rules according to which the "group" affected by prima facie unlawful practices can be identified, so that their individual, usually "low value" claims can be aggregated into a representative lawsuit. For this purpose, it is therefore indispensable to identify, among all those individuals or legal entities active on a specific market, those who have actually been adversely affected by the consequences of the defendant's

134 Elzinga and Breit, The Antitrust Penalties: a Study in Law and Economics

(1976, New Haven, CT: Yale University Press), pp. 3-4.

135 Inter alia, Issacharoff, op. cit. (fn. 132), p. 145.

136 See e.g., Mulheron, op. cit. (fn. 132), p. 62. 
conduct and can therefore stand in judgment against her. This inquiry will focus on the rules governing standing in competition cases. ${ }^{137}$

It is accepted that the standing conditions governing the lodging of competition claims vary from jurisdiction to jurisdiction and can be framed widely or narrowly according to the policy choice made by each legal system. Thus, for instance, Section 4 of the US Clayton Act confers standing to sue to "any person who shall be injured in his business or property by reason of anything forbidden by the antitrust laws [...]". Although the US Supreme Court forcefully stated that, on face value, Section 4 contained "little in the way of restrictive language", 138 it emphasized in a number of judgments that standing should be reserved only to those claimants who could allege losses that the Act had been designed to forestall. 139

Thus, in Brunswick it was held that the "potent" remedy enshrined in Section 4, that is, the award of treble damages, should be available to compensate harm that was a direct consequence of the adverse impact of prima facie unlawful behaviour on competition. ${ }^{140}$ In the Court's view, losses arising from an increase, as opposed to a reduction of competition would not be among those that the Clayton Act had been enacted to prevent. ${ }^{141}$ In the McCready decision the Supreme Court further explained that the standing inquiry should also encompass a prima facie assessment of the existence of a causal link between the claimed injury and the alleged infringement: ${ }^{142}$ if the claimant could make a preliminary showing that the alleged loss was a "clearly foreseeable" consequence of the means "by which [the respondent] had sought to achieve its illegal ends", she could stand in judgment against them. ${ }^{143}$ In the later Associated General Contractors decision the Supreme Court held that in conducting this assessment a number of factors would be relevant, namely the nature of the loss allegedly suffered by the plaintiff and especially its proximity to those forms of loss that the Act had been

137 See e.g. case C-295/04, Manfredi, op. cit. (fn. 36), para. 61; also Lang, op. cit. (fn. 131), pp. 295-296.

138 See e.g. Blue Shield of Virginia v McCready, 457 US 465 at 472; for commentary, inter alia, Areeda and Hovenkamp, op. cit. (fn. 108), pp. 68-70; also Jones, op. cit. (fn. 29), pp. 168-169.

139 See e.g. Reiter v Sonotone Corp., 442 US 330 at 337; also Brunswick v Pueblo-O-Mat, 429 US 477 at 484-485.

140 Brunswick, op. cit. (fn. 139) at 488.

141 Ibid.

142 Blue Shield of Virginia v McCready, 457 US 465 at 477.

143 Ibid., at 478. 
designed to prevent, the type of prima facie unlawful practice and the degree of speculation affecting the appraisal of the existence and size of the alleged harm. ${ }^{144}$

It is therefore already clear from this cursory examination that in spite of the prima facie "generous language" used in Section 4 of the US Clayton Act, the US Federal Courts have come to adopt a relatively cautious and consequently, "selective" approach to assessing antitrust standing. In this context the notion of "antitrust injury" was relied upon as a means of limiting the spectrum of admissible claims only to those that stem prima facie directly from a loss of rivalry, either as a result of collusive behaviour or as a consequence of monopolization. ${ }^{145}$ It is emphasized that these considerations are all the more relevant when considering whether collective claims can be adjudicated via opt-out class actions, certified under Rule 23(b)(3) FRCP. As will be examined in more detail in later chapters, the US Federal Courts have become increasingly cautious in appraising whether the three elements of a prima facie breach of the antitrust rules - that is, the existence of either an unlawful conspiracy to restrain trade or of a unilateral act or attempt of monopolization, the occurrence of direct injury to the claimants' business or property and the existence of a nexus of causality between the practice and the loss suffered by each member of the proposed class - can be established through proof common to all the class members. ${ }^{146}$

The Federal Courts have been especially exacting in their inquiry to ensure that evidence of "antitrust injury" should be "class wide", out of a concern for preventing a "plethora" of mini trials that may otherwise be necessary to appraise the different impact of the practice on business or property of individual class members, even though in principle the claim being lodged arose from the same "nucleus of facts". ${ }^{147}$ As a result, and although this inquiry may acquire different nuances due to the different range of allegations made by the plaintiffs, ${ }^{148}$ it may be suggested that, in order to strike a balance between the fairness of representative litigation

144 Associated General Contractors of California Inc v California State Council of Carpenters, 459 US 519 at 538-539.

145 Ibid., at 541-543; see also Brunswick, op. cit. (fn. 139), at 488; cf., e.g., Illinois Brick Co v Illinois, 431 US 720 at 744-745.

146 See, inter alia, Weeks v Bareco Oil Co, $125 \mathrm{~F} 2 \mathrm{~d} 84$ at 91; for commentary, see e.g. Advisory Committee's Notes to proposed rules of Civil Procedure, 39 FRD 69 at 103.

147 See e.g. In Re: Potash Antitrust Litigation, 159 FRD 682 at 695-696; for commentary, see, inter alia, Newberg, 4th edn, para. 18.25.

148 See e.g. Ungar et al. v Dunkin' Donuts Inc, 531 F2d 1211 at 1224. 
and the "efficient" administration of justice, the standing inquiry under Section 4 of the Clayton Act and especially the concept of antitrust injury has proven to be an effective "filter" for access to the US Federal Courts. ${ }^{149}$

This relatively "selective" standing inquiry can be contrasted with the locus standi criteria enshrined in the case law of the Court of Justice of the EU: as anticipated, the Court held in Manfredi that "any individual" could stand in judgment to recover damages suffered as a result of anti-competitive behaviour only subject to the establishment of a direct causal link between the prima facie unlawful practice and the harm claimed. ${ }^{150}$ Consequently, it could be argued that since the Court made no mention of the need to prove the existence of "special" injuries or of fault or negligence on the part of the defendant, the standing rules enshrined in Manfredi seem more generous than those elaborated under Section 4 of the Clayton Act. On this point, it should be emphasized that this inquiry is subject, in any event, to the application of the general principle of national autonomy, according to which it is for domestic law to determine, subject to the usual caveats of "equivalence" and of "practical possibility", ${ }^{151}$ the rules and criteria through which to establish the existence of this causal link, the resulting liability and the size of the loss suffered by the claimant. ${ }^{152}$

Against this background, it is argued that, "generous" though it may seem at first glance, the standing test contained in Manfredi may become quite complex to satisfy in individual cases, due to the differing rules governing tort liability in each Member State. Thus, for instance, the British Courts have sought to develop a relatively wide notion of standing, in accordance with Section 47A of the Competition Act 1998: on this point, the Court of Appeal held in $B A S F$ that anyone who suffered the adverse consequences of a prima facie competition infringement could stand in judgment to seek compensation. ${ }^{153}$ By contrast, the Italian

\footnotetext{
149 See, inter alia, Illinois Brick Co v Illinois, 431 US 720 at 744-745.

150 Case 295/04, Manfredi, op. cit. (fn. 36), paras 60-62.

151 Ibid., para. 62, see also paras 95-96.

152 Ibid., paras 98-99; see also 2008 White Paper, text to fnn. 3 and 4; also 2008 Impact Assessment Document, para. 165. For commentary, inter alia, Eilmansberger, "The Green Paper on damages action for breach of the EC anti-trust rules and beyond: reflections on the utility and feasibility of stimulating private enforcement through legislative action" (2007) 44 CML Rev 431, especially pp. $456 \mathrm{ff}$.

${ }_{153}$ BCL (Old Co) Ltd v BASF SE, [2010] EWCA (Civ) 1258, per Loyd J,
} para. 10 . 
courts not only have long denied competition standing for consumers, ${ }^{154}$ thus in practice limiting standing to rivals, ${ }^{155}$ they also subjected the assessment of liability to often inconsistent criteria, going as far as sometimes questioning the extent to which the Courts of Appeal competent to hear these claims would actually be capable of deciding them. ${ }^{156}$

In light of the foregoing analysis, it is suggested that despite the absence of a notion akin to that of "antitrust injury", access to the domestic courts within the EU may often be more complex than could have been thought only on the basis of Manfredi. It is acknowledged that this position constitutes a predictable consequence of the application of the principle of national autonomy. ${ }^{157}$ However, it is equally apparent that without overall consistent rules governing antitrust standing and liability for "transnational" infringements of Articles 101 and 102 TFEU, the application of this principle may lead to significant inconsistencies in the enforcement of the right to damages recognized by EU law to individual or collective claimants and could even go so far as to question the practical possibility of its exercise in specific cases. ${ }^{158}$ These concerns are likely to be even more pressing in respect to collective lawsuits: as was illustrated above, this is an area where disparities across the Union are particularly significant. ${ }^{159}$ Although it could be argued that the efforts made by the Commission to pave the way for a common legal framework in this area are no longer made in a "legal vacuum", it is clear that the

154 See e.g. UNIPOL, judgment of the Court of Cassazione (SU), 17 October 2003, No 15538 FI (2003) I 2938; for commentary see Carpagnano, "Private enforcement of competition law arrives in Italy" (2006) 31(2) CompLRev 47, especially pp. 53-54.

155 See e.g. AXA, decision of the Court of Cassazione (V), 9 December 2002 No 17475, FI (2003) I, 1121; for commentary, see Carpagnano, op. cit. (fn. 154), pp. 55-57.

156 See e.g. SAI, decision of the Court of Appeals of Naples, 5 May 2005, (2005) FI I 1880; for commentary, see Carpagnano, op. cit. (fn. 154), pp. 59-61. 157 See e.g. 2008 White Paper, text to fnn. 3 and 4; also 2008 Impact Assessment Document, para. 165; for commentary see, inter alia, Cengiz, "Antitrust damages actions: lessons from US indirect purchasers' litigation", (2010) 59(1) ICLQ 39 at 52.

158 See e.g. Impact Assessment Document, para. 70; also, Cengiz, op. cit. (fn. 157), pp. 53-54.

159 See, inter alia, Norwegian Disputes Act (No 90/2005), Chapter 35; Portugal: "Actio Popular", provided by the Right of Proceeding, Participation and Popular Action Law No 83/95. For commentary, see Peyer, op. cit. (fn. 54), pp. $45-47$. 
domestic solutions that have so far been adopted vary significantly among the Member States that have enacted measures in this area. 160

Consequently, it is concluded that, in principle, encouraging convergence around a common core of principles designed to facilitate group action in "mass harm" cases, and at the same time seeking to adopt binding measures to improve access to justice in competition claims more specifically, could represent an effective response to the perceived need to strengthen the ability of small claimants to obtain relief of their losses. ${ }^{161}$ It is, however, unclear how this approach will work in practice. As will be illustrated in more detail in Chapter 7, it is especially difficult to foresee "how fast" and "how far" the Commission's proposed approach to collective redress will be accepted and, consequently, embedded in the domestic laws of the Member States in a way that minimizes delays and the risk of fragmentation.

\subsection{Access to Justice in EU Competition Damages Cases - Where Now?}

The previous sections briefly discussed some of the likely causes for the paucity of competition lawsuits in Europe and on that basis illustrated the trends guiding the EU Commission's efforts to address these pressing concerns. It was argued that although the Commission seems to have decidedly moved away from seeking to devise a "competition collective lawsuit", it still considers collective litigation as a key complement to the effective enforcement of "public interest" legal rules, among which competition law features prominently. For these reasons it was suggested that, as will be explored in Chapter 7, the 2013 Recommendation on Collective Redress seems to emerge as an indispensable tool to reinforce the right of the victims of competition infringements as "mass harm situations" vis-à-vis a common alleged tortfeasor.

However, it was also emphasized that the way in which the Commission has designed its approach to these forms of legal action is going to be critical for the achievement of greater access to justice, and for establishing fairness and the sound adjudication of complex disputes. Thereafter, the chapter briefly examined some of the general questions surrounding the function of private litigation in the context of the application of the competition rules in the US and the EU and argued that

\footnotetext{
160 See, inter alia, Eilsmanberger, op. cit. (fn. 152) pp. 441-442.

161 See e.g. 2008 Impact Assessment Document, paras 37-38; see also para. 54 and 165; see also 2011 Consultation document, para. 10. For commentary see e.g. Eilsmanberger, op. cit. (fn. 152), p. 443.
} 
their "public interest" nature would provide a powerful justification in favour of these cases being litigated collectively. In this specific respect, it was emphasized that the nature of the objective of genuine competition as a "common good" represents a convincing rationale for collective action in this area.

The remainder of this chapter will address a number of theoretical questions concerning how to frame collective legal actions in order to achieve its public interest objectives fairly as well as effectively. In this context, it will be observed that two questions are especially relevant, namely: first of all, how to "aggregate" the members of a sizeable and "dispersed" group into a relatively homogenous and "consistent" whole on behalf of which a representative lawsuit can be brought; and secondly, how this form of action can be "managed" so that it can serve the interests of the group and at the same time respect the constraints dictated by principles of sound justice and due process.

\section{ANTITRUST LITIGANTS AS A "LATENT" GROUP: MOBILIZATION AND INCENTIVES IN COLLECTIVE COMPETITION LITIGATION}

\subsection{Introductory Remarks}

The previous sections provided a snapshot of the issues concerning group litigation in the EU, both generally and in the context of competition enforcement, and emphasized how collective redress has constantly been regarded as a promising instrument for boosting these actions, due to the "diffuse" nature of competition damages and the perception of the goals of competition enforcement as a "public good". In this respect, the brief analysis of the standing conditions governing these actions in the US and the EU respectively allowed for the examination of the criteria through which the "group" of prospective litigants can be identified and circumscribed within the "general public" for the purposes of litigation.

The following sections will consider in more detail how large groups, such as those affected by the consequences of widespread competition infringements can be encouraged to take action for the purpose of obtaining compensation for the harm suffered as a result of anticompetitive conduct and thereby also contribute to the overall deterrence of future unlawful behaviour. Using the taxonomy of groups and the economic theoretical framework developed by Mancur Olson, the text will consider how a large, "latent" group of individuals or firms, such as 
those affected by anti-competitive behaviour, can be "mobilized" and made to form a "unitary" collective litigating body. It will be argued that any proposal seeking to facilitate the bringing of these actions collectively should consider whether any "incentives" can be created to pursue this objective and also examine ways in which the "group lawsuit" can be "managed" so as to provide effective redress of the damage caused to the litigants and comply with the needs of the sound administration of justice.

Finally, the chapter will discuss the theoretical framework developed in response to the demands and features of class litigation in the US, and in particular will highlight that the promise of "enhanced damages" and the derogation from the "American rule" as a way of mitigating the "threat" of court costs and lawyers' fees, has been decisive in encouraging the lodging of new class action, especially by fostering an "entrepreneurial model" of class counsel. However, it will be argued that the reliance on class counsel as the "engine" for new class litigation, while being indispensable for new actions to reach the courts and ultimately for the attainment of the public interest goals of antitrust and other "public interest statutes", requires particular care so as to avoid that counsel, being left largely independent in "managing" specific claims, may engage in practices designed to maximize her own profits to the detriment of the class.

For these reasons, it will be concluded that judicial supervision of the litigation, to be exercised both at the admissibility stage and at the conclusion of class proceedings, represents an indispensable tool to secure the integrity of the interests of the class and the sound adjudication of the claim lodged on its behalf and, eventually, to maintain the fair and efficient administration of justice - especially at the admissibility stage

\subsection{Antitrust Litigants as a "Latent" Group: Issues Concerning their "Mobilization", their "Management" and their Overall "Effectiveness"}

\subsubsection{Mancur Olson's "taxonomy" of groups and logic of collective action in aggregated antitrust litigation: brief remarks}

A detailed consideration of the implications of Mancur Olson's theories on the rationale and modes of collective action is clearly beyond the limits of this work. However, it is indispensable to consider some of the 
major aspects of Olson's "logic of collective action"162 so as to provide the background for the analysis of the modes of aggregation of private antitrust claims into group lawsuits. Olson's studies focused mainly on the labour movement as well as on more general aspects of group action. ${ }^{163} \mathrm{He}$ sought to explain the "ubiquitous" presence of collective organizations, either formally constituted or having a less defined and more informal structure, ${ }^{164}$ as a consequence of the perception on the part of a number of individuals holding a "common interest" that acting together would be more effective in achieving this common objective as opposed to taking individual action. ${ }^{165}$

It was argued that acting collectively would allow each member of the group to offset, at least in part, the costs associated with securing the collective good - costs that would be shared across the group itself - thus making it more rational for them to act as a group than individually. ${ }^{166}$ In this context, Olson emphasized that the propensity to "pay" - that is, to bear at least part of these costs - for the collective good often varied throughout the spectrum of the group: he pointed out that whereas some participants may be willing to shoulder all the costs involved with acquiring it, others may be inclined to enjoy the collective good virtually "for free". ${ }^{167}$ Against this background, he argued that collective action in this context would still be a "rational option" since the participation of more "active" members of the group was sufficient to provide all the interested individuals with the collective good in any event. ${ }^{168}$

The propensity to act collectively, however, does not necessarily mean that the "collective good" will be provided to all the group members at an "optimal" level, that is, in the quantity needed to satisfy the demands of each participant. ${ }^{169}$ Issues concerning the size of the group and the non-excludable nature of "collective goods" often demand the existence of some form of "coercion" on the members of the group, to force them to contribute to the costs associated with their supply and thereby avoid

162 Olson, The Logic of Collective Action (1963, Cambridge, MA: Harvard University Press) (hereinafter referred to as "Olson").

163 Olson, pp. 7-8.

164 Ibid., pp. 17-18.

165 Ibid., pp. 19-21.

166 Ibid., pp. 34-35.

167 Ibid., p. 35.

168 Ibid.

169 Ibid., pp. 35-36. 
that the amount of collective benefit may fall shorter of the "optimum". ${ }^{170}$ It was illustrated that even "well-motivated" group members may lose the incentive to "pay" for the collective good before that "optimum" is reached due to the circumstance that, as a result of the impact of the "free consumption" by less "motivated" members, she perceives a lesser advantage from the expenditure incurred. ${ }^{171}$ This can in turn have an adverse effect on the willingness of the "non-paying" members to contribute in the future: since the amount of the collective good they can receive for free is decreasing as a result, they will be less inclined to "pay their share" for future consumption episodes. ${ }^{172}$

It is against this background that issues concerning the "size" of the group should be considered: it is self-evident that in small groups a degree of "coercion" to contribute in some way to the effective functioning of the organization can be exercised through "informal" channels. ${ }^{173}$ It was pointed out that when there are only a few members in a group their behaviour as individuals tends to have a noticeable impact on the welfare of the other members: it follows that their "reaction" will often be an effective means through which any "misbehaving" members can be brought back in line and "forced" to act once more in the interest of the group. ${ }^{174}$ If, instead, the group membership is so large that the consequences of the action or inaction of each member cannot immediately be perceived by others, it is indispensable to introduce a form of coercion to induce the membership to act in their own common interest, such as a "group agreement", imposing a set of "duties" on individual members. ${ }^{175}$

Consequently, the issue of group sizes raises a number of questions concerning the "costs" associated with the running of these organizations, as well as the degree of "complexity" required for the group to function. ${ }^{176}$ Since the larger the group is, the likelier it will be that the collective good will be supplied in smaller quantities, the more complex, coercive and thus costlier the organization will have to be in order to

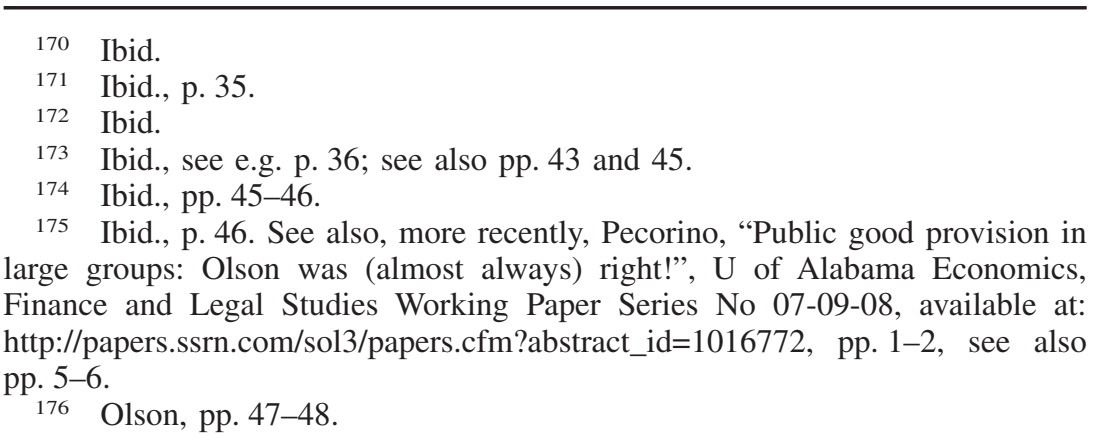


discharge its function of purveying that good effectively. ${ }^{177}$ Olson sought to distinguish different types of groups: drawing an analogy between collective organizations and market structures, he sought to distinguish between "privileged", "intermediate" and "latent" groups. ${ }^{178}$

To the first category belong groups of small size, in which each member, in as much as she is aware of the impact of her actions on others as well as having a personal incentive to obtain the public good, will "see that [...] [the latter] is provided", 179 even by "footing the bill" herself entirely. ${ }^{180}$ In this sort of group there is therefore a "presumption" that the collective good will be provided, regardless of whether there is an "organization" devoted to this objective. 181 "Intermediate groups" are instead those groups whose size is more considerable but not as large as not to allow each member to notice other members' inaction: in these circumstances, while it is likely that the collective good will be provided, some degree of "organization" is nonetheless required since, due to its very size, no member obtains a "share" of the good that is such as to give her an incentive to act independently for that purpose. ${ }^{182}$

"Privileged" and "intermediate" groups can be contrasted with "latent" groups: these are of very large size so that even if one or more of its members remain inactive, the others will not be adversely affected and therefore will have no incentive to react or indeed to make a "noticeable contribution to any group effort". ${ }^{183}$ Consequently, a question emerges as to how these large groups may be "mobilized", that is, made to act together in the pursuit of the common good. ${ }^{184}$ On this point, Olson argued that since in a large group the propensity to bear the costs associated with obtaining this common good is inevitably likely to vary significantly across the spectrum of their membership, it would be indispensable to provide each participant with an incentive to be drawn into common action. ${ }^{185}$ It was emphasized that whatever "incentive" was promised - whether a "punitive" one or a "positive" incentive such as a

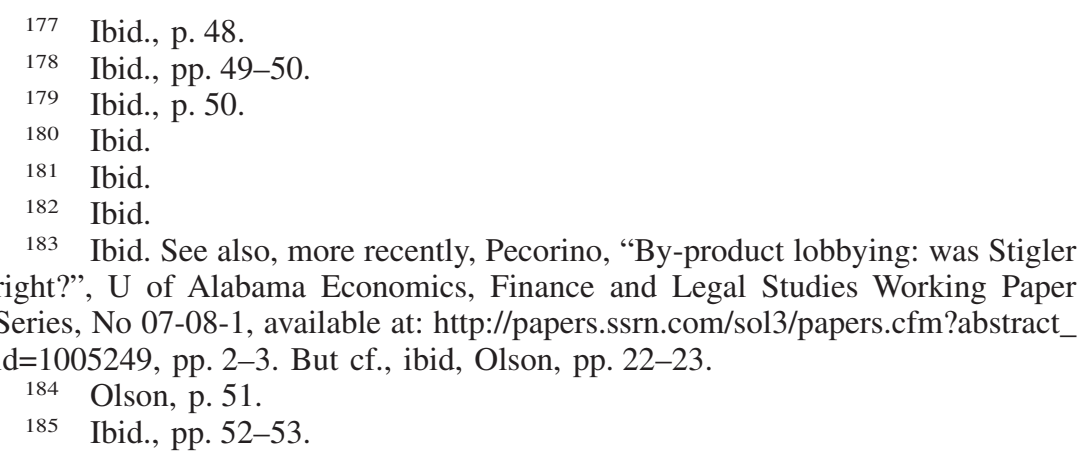


reward or prize - it would have to be "selective":186 in other words, it must only be available to the individuals who are willing to commit to the common action. ${ }^{187}$

"Mobilizing" a large group, however, does not necessarily guarantee the "success" of the common action, namely the provision of the common good in the quantity needed to satisfy the demands of each member. To achieve its "optimal supply" it is indispensable to create a mechanism, more or less formal, for the "management" of the group. ${ }^{188}$ This task must also be performed as far as possible "autonomously", that is, in the exclusive interest of the group as a whole, as opposed to pursuing the interests of individual class members. ${ }^{189}$ Although the "autonomy" of those entrusted with the management of the collective action was regarded as indispensable for the overall success of their action, ${ }^{190}$ it was observed that due to the large size of the group, the individuals responsible for this task would enjoy a relatively unconstrained freedom of action. On this point, it was also suggested that, since each member can only aspire to enjoy a small quantity of the common good being pursued, they would have a correspondingly small incentive to "go after" the management if it was alleged that the latter had acted against the interests of the group. ${ }^{191}$

In light of the foregoing analysis, an analogy was drawn between "latent groups" and the management of large public companies, whose shareholders are very numerous and therefore in control of small shareholdings. ${ }^{192}$ Olson expressed the view that since they could only aspire to small dividends, they would have a correspondingly small incentive to challenge the company's officers, even in light of prima facie serious allegations of misconduct. ${ }^{193}$ These conclusions were confirmed, inter alia, by a relatively recent study on shareholders' rights and their ability to successfully oust corporate managers. According to the data gathered by Bebchuk, these challenges have only been successful in a

\footnotetext{
186 Ibid., p. 52.

187 Ibid., p. 51. But cf. Pecorino and Temimi, "Lotteries, group size and public good provision", U of Alabama Economics, Finance and Legal Studies Working Paper Series, No 05-04-01, available at: http://papers.ssrn.com/sol3/ papers.cfm?abstract_id=1066067, pp. 2-3.

188 Olson, pp. 53-54.

189 Ibid., p. 55.

190 Ibid.

191 Ibid.

192 Ibid. See more recently Bebchuk, "The myth of the shareholders franchise" (2007) 93(3) Va. L. Rev. 675 at pp. 687-689.

193 See, inter alia, Bebchuk, op. cit. (fn. 192), p. 688.
} 
relatively small proportion of cases: of 303 attempted challenges which occurred between 1996 and 2005 across a sample of relatively diversified companies, only 45 in total were successful: however, when considering the actual size of the corporation, it was found that only eight related to large ones, that is, to companies whose market capitalization was worth $\$ 200$ million or more, and whose shareholders can be considered as constituting a "latent" group. ${ }^{194}$

As to the "causes" of this lack of success, it was found that the "costs" associated with identifying, making contact with and "persuading" shareholders to vote for a "newcomer" represented a considerable hurdle for challengers, if not the most considerable one. ${ }^{195}$ In other words, it would appear that the costs associated with "mobilizing" the latent group in question were such as to block many of the attempts at challenging incumbent corporate officers. ${ }^{196}$ In light of the above considerations, it could be tempting to assume that, just because of the "numbers" potentially involved, the collective action of large groups may often not be successful. However, this is often not the case in practice: although "mobilizing" and "managing" the action of large groups presents challenges, it is equally clear that these groups can successfully "copy" the methods adopted by smaller groups and therefore engage successfully in collective action. ${ }^{197}$

It is suggested that in doing so the emphasis should no longer be placed on "informal" methods of coercion (such as those based on the idea of "kinship") ${ }^{198}$ but on exploiting the profit-maximizing tendencies existing in each individual, thereby creating a rational incentive to pursue the common good together with the other group members. ${ }^{199}$ But how can this overarching objective be achieved? While the limited remit of this work does not allow a more extensive analysis of the dynamics of large groups, it is clear from the above that Olson's approach provides numerous insights into the functioning of wide classes of individuals sharing common interests. The foregoing analysis showed that one of the key obstacles to individuals pursuing common, non-excludable goods is represented by the costs associated with taking an active role in procuring them. The theoretical framework illustrated above showed that the larger the group, the more difficult it is to attract individual members of these

\footnotetext{
194 Bebchuk, op. cit. (fn. 192), p. 688.

195 Ibid., pp. 690-692.

196 Ibid., p. 692.

197 Olson, p. 57.

198 Ibid., pp. 60-61.

199 Ibid., pp. 64-65.
} 
latent groups into participating in common action, even when the collective good being sought is of social importance. Against this background it is argued that other factors should be put in place to encourage this participation. To this end, Olson advocated shifting from "social coercion" to the provision of "external incentives" designed to exploit the rational tendency, present in all individuals, to act in their own interest. The next section will examine what incentives can be offered so that these objectives can be met.

\subsection{2 "Mobilizing" members of large groups: the "by-product" as an incentive to act in the common interest}

Section 4.2.1 sought to give a brief account of Mancur Olson's theoretical framework for the analysis of collective action and in that context highlighted the link between group size and the effectiveness and efficiency of this type of action for the pursuit of a common good. This section will consider Mancur Olson's response to the question of what type of "incentive" can be devised in order to call "latent groups" into action. As was anticipated in the previous section, Olson's studies focused mainly on trade unions and other large interest groups active in the area of "occupational-industrial representation", 200 drawing on a "pluralistic view" of democratic society, that is, a society where the state as a communal organization, devoted to the provision of some collective goods that the market could only supply inefficiently, ${ }^{201}$ should not have "unlimited control" over individuals and where instead "labor unions, churches and cooperatives" should have a more important role designed to "counterbalance", in some way, the "coercive" nature of state power. ${ }^{202}$ It was argued that these kinds of collective organizations, being the "offspring" of individual freedom, should be positively valued not just as an "independent, voluntary spontaneous outgrowth", ${ }^{203}$ but also as a means through which diverse and often conflicting interests could be represented and reciprocally balanced, "pressure groups" emerged as "fundamental determinants of economic and political behavior", 204 being a perhaps closer proxy to their members than the "proper" political, territorially organized and representative organizations and, therefore, ultimately as key factors for the determination of governmental policy, ${ }^{205}$

\footnotetext{
200 Ibid., p. 114.

201 Ibid., pp. 99-102.

202 Ibid., pp. 111-112.

203 Ibid., p. 113.

204 Ibid., p. 117.

205 Ibid., pp. 118-120.
} 
without, however, threatening the stability of that democratic, representative government.206 Their role and importance is, therefore, broadly consistent with democratic principles and with the concern for protecting both personal freedom and the legitimate interests of homogenous groups. 207

Nonetheless, one of the perceived "weaknesses" of these accounts of the emergence of collective organization lies in the lack (or at the very least in the less convincing consideration) of "why" individual members may wish to associate themselves with them. ${ }^{208}$ Olson emphasized how, for all their concern with the "common interests" of their members, groups relied heavily on the "self-interested nature" of individuals, that is, on their concern for their own welfare which may be served by the action of collective bodies ${ }^{209}$ - simply because an interest is shared by a number of "potential members" these individuals may not necessarily act spontaneously to achieve it by common means and may be especially reluctant to bear some of the associated costs. ${ }^{210}$ Drawing from the analysis of trade union practices in the US, Olson argued that large collective bodies could perform their institutional functions effectively only by "promising" to their potential members to supply them with a "selective incentive", that is, an incentive available only to those participating in the collective action, so as to encourage them to take part in it. ${ }^{211}$

Although he acknowledged that these incentives could be "positive" or "negative" - the latter being based on the "naked coercion" of would-be members to adhere to the collective action ${ }^{212}$ - Olson observed that it would be rather unusual if, in a democratic society, collective bodies could compel individuals to associate themselves with an organization, however laudable its objectives may be. ${ }^{213}$ Consequently, it was suggested that in addition to performing their institutional mission, that is,

\footnotetext{
206 Ibid., p. 125.

207 Ibid., pp. 123-125.

208 See ibid., pp. $125 \mathrm{ff}$.

209 Ibid., p. 126.

210 Ibid., pp. 126-127.

211 Ibid., pp. 130-131; see also, mutatis mutandis, more recently, Kahan, "The logic of reciprocity: trust, collective action and law", Yale Law School, Centre for Law, Economics and Public Policy Research Paper No 281, available at http://papers.ssrn.com/abstract=361400, especially pp. 1-2 and 9-12.

212 Olson, p. 133.

213 Ibid.
} 
their activity in pursuit of a specific common good, collective organizations should also engage in the provision of non-collective goods, whose supply is designed to induce individuals, whose interests are common with those pursued by the organization itself, to align themselves with the organization's action. ${ }^{214}$ In Olson's view, short of negatively coercing individuals into becoming "active participants" to their efforts, collective bodies could only seek to induce them to support their "mission" through the promise of a reward or prize that was only available to members, thus becoming the "by-product" of the organization's institutional activity. ${ }^{215}$

It was acknowledged that the "by-product" doctrine cannot provide an explanation for every case of successful collective action. For instance, Olson recognized that many philanthropic or religious organizations, in as much as they are animated by non-economic goals and principles, cannot be satisfactorily explained only in terms of "rational" and "profit-maximizing" behaviour or of "selective incentives", for the very reason that for them membership is motivated by reasons going often "beyond reason". ${ }^{216}$ However, it should be recognized that Olson's "by-product" theory appears to be confirmed by the type of action adopted by several lobbying organizations, of a social, economic and political nature, such as trade unions, industry and trade associations and farming bodies, which will be considered in the next section.

\subsubsection{Olson's theory put to the test: labour organizations and farming associations ... and why governmental action matters!}

The previous section sought to give a brief account of the "by-product" theory and in that context argued that when "latent groups" are at issue, the pursuit of a "collective good" by a specific representative body is only possible if the former are mobilized into action through the supply of a non-collective good. This section will try, albeit within the limits of this work, to "test" Olson's theory by reference to specific collective organizations, such as trade unions and the labour movement. It has been argued that the importance of labour organizations as a "political force" stems from the "purely industrial activities" that they perform, that is their collective bargaining with employers, often leading to the negotiation of "closed shop clauses". ${ }^{217}$ In this context, being a member of a

\footnotetext{
214 Ibid., p. 134.

215 Ibid.

216 Ibid., pp. 159-161. Cf., e.g. Kahan, op. cit. (fn. 211), p. 2; see also pp. $10-12$.

217 Olson, p. 135.
} 
union constitutes a de facto requirement for being hired by specific employees in unionized firms, an outcome which, in turn, represented a strong "incentive" for individuals to join unions. ${ }^{218}$ As a result, it was suggested that this indirect incentive to adhere to a trade union allowed the labour organizations to maintain their existing members as well as to increase support and, eventually, to reinforce their "institutional" role in industrial relations and in political lobbying. ${ }^{219}$

Broadly similar considerations were also made in respect to professional bodies, such as the local "Bar" or "Law Societies" or trade associations representing medical professionals. Although these collective organizations differed from trade unions on the ground that they did not rely on "closed shop" arrangements, they sought to make membership more and more indispensable, if not altogether compulsory for other reasons. ${ }^{220}$ For instance, compulsory membership of organizations representing legal professionals has historically been justified on the ground that by becoming a member, each provider of legal services would be subject to disciplinary powers exercised by the organization to the benefit of clients and eventually in the public interest.221 Perhaps more importantly, it was illustrated that even when membership is not "overtly" compulsory, it may become de facto essential due to the importance and the value attached to the services offered by the organization. ${ }^{222}$ The example of the service of "skilled malpractice defence" offered by the American Medical Association to its members represents a telling example of a more "subtle" form of coercion to join permanently this organized body as well as providing a key factor in boosting its role as a lobbying organization. ${ }^{223}$

The "by-product doctrine" is especially helpful when it comes to assessing the extent to which external factors, such as the intervention of public authorities, including the legislature, can influence the effectiveness of these selective incentives, namely their ability to make the option of joining the collective action more attractive in the eyes of potential participants and, as a result of increased support, more effective. Olson sought to explain the impact of public authorities on lobbying organizations in light of the development of farming unions and associations in the US in the early 1900s.

\footnotetext{
218 Ibid.

219 Ibid., pp. 135-136.

220 Ibid., pp. 137-138.

221 Ibid., p. 139.

222 Ibid.

223 Ibid., pp. 139-141.
} 
He traced the development of the American Farm Bureau Federation 224 from county organizations designed to assist agents, who were partfunded by government, in distributing information on new farming methods to their members, to more "official" collective bodies: although their role was sanctioned by legislation ${ }^{225}$ and financed publicly, these organizations did not rely on compulsory membership. ${ }^{226}$ Nonetheless, they became, at least for a time, very popular due to the nature of the services they provided to their members, that is, education, technical assistance and information on possible farming improvements. ${ }^{227}$ In other words, and just as with trade unions, their ability to supply a valuable benefit exclusively to their members constituted an "informal" incentive to join and therefore allowed them to perform their lobbying tasks effectively on behalf of the agricultural community. 228

However, their membership started to dwindle steadily after 1921 and had dropped by nearly two-thirds by 1933 , an era in which there was every reason to suppose that farming information would be particularly relevant for individual would be members. This was also a period in which important changes to the American Farm Bureau Federation scheme were introduced: individual bureaus started taking on new functions and in particular started to promote other organizations active in the same field of agriculture support, thus spearheading competition in their lobbying activity. 229

In response to these changes, the legislature, who was still in control of part of the funding destined for the bureaus, "got in the way": it took action to change the "job specification" of county agents, by restricting the extent to which they could act on behalf of or to the benefit of the bureaus. ${ }^{230}$ The new measures also allowed individual members to access agents directly, instead of going through the bureaus. ${ }^{231}$ Consequently, as the "selective incentives" offered by them, among which was the assistance of the agents, became less valuable, especially due to the presence of alternative providers of similar services, the trend towards

\footnotetext{
224 Ibid., pp. 148ff.

225 Ibid., p. 149-150.

226 Ibid., p. 150.

227 Ibid.

228 Ibid., p. 150.

229 Ibid., p. 151.

230 Ibid.

231 Ibid., pp. 151-152.
} 
joining up started weakening 232 and eventually resulted in the bureau's demise, to the advantage of rival, elective organizations. ${ }^{233}$

Against this background, it is argued that external action, and especially governmental intervention affecting the "selective incentives" offered by collective organizations to attract new members, can have a distinct impact on the organizations' weight in society and in the economy. The sketch of the American Farm Bureau Federation experience has shown that the intervention of public authorities, often in response to political pressure, on the nature and availability of the non-collective goods or services offered by the organization as its "by-product" directly influences their ability to "coerce" them, albeit indirectly, into adhering to the organization itself. As Olson aptly put it, since "large pressure-group organizations [...] derive their strength as by-product of some non-political function" - in the case of the Bureaux, a combination of the role of the county agents and of the Bureaux's ability to supply non-collective goods such as technical assistance to members - they start losing their importance and thus their ability to perform their "institutional function" once the "incentive" for "rational individuals to join the organization, even if they were in complete agreement with its policies", goes amiss or diminishes. ${ }^{234}$ The circumstance that for the Bureaux this change was caused by legislative action shows that public authorities can enhance or weaken selective incentives and thereby influence the effectiveness and efficiency of collective action to secure common goods. ${ }^{235}$

In light of the above, it may be queried whether this relationship of "reciprocity" existing between the offer of a "by-product" and the willingness to adhere to collective action can be usefully applied to all forms of group action. As was anticipated in the previous section, Olson's model relies on the assumption that individuals behave rationally, that is, always so as to maximize their utility. Consequently, it could be argued that the theoretical framework he suggests cannot explain "why" individuals become involved in collective bodies whose objectives are not of

232 Ibid., p. 152.

233 Ibid. But cf., more recently, J.I. Stewart, "Why did farmers belong to interest groups? Evidence on the causes of membership from the Farmers' Alliance", available at: http://papers.ssrn.com/sol3/papers.cfm?abstract_id= 1614183, pp. 6-7.

234 Olson, pp. 156-157.

235 Ibid., pp. 157-158. 
"economic" nature, such as religious groups. ${ }^{236}$ On this point, it was added that the reliance on the idea of individuals as "profit maximizers" cannot fully explain also why citizens share the propensity to pay taxes: on this point, Kahan, for instance, argued that the assumption of "rationality" and of "profit-maximization" as a common characteristic for human behaviour should justify tax evasion, as opposed to fiscal compliance. ${ }^{237}$ Consequently, this commentator suggested that "impulses" that are not inherently rational, such as the prospect of shame or of "potential stigma" characterizing tax evasion, played a decisive role in securing tax compliance, acting perhaps more effectively than any desire to "maximize profits" via the enjoyment of services offered by the State. ${ }^{238}$

The foregoing discussion also shows that successful collective action among large groups almost inevitably started in groups sharing well defined common interests. Legal professionals, medical doctors, farmers - all these groups hold well defined collective concerns. By contrast, other large groups often share less defined or consistent interests: consumers, for instance, are often "silent sufferers" who, despite holding broadly common interests, such as the concern for the safety of massmarketed products, remain unrepresented and passive even in the face of significant harm being suffered as a result, for instance, of the supply of harmful goods. ${ }^{239}$ Against this background, the question is how these "latent", "passive" groups can be "mobilized" into taking collective action designed to achieve common goals that are clearly worthy of protection in the public interest. It could be argued that according to Olson's framework, the promise of a "selective incentive" designed to entice individual members should represent an effective tool to encourage them to adhere to existing collective actions or even to initiate new ones. However, the experience in the area of, inter alia, consumer protection demonstrates that consumer groups tend to "react" to the consequences of harmful conduct or events (such as the consequences of an infringement of the competition rules having a widespread impact on the market) via collective action only in limited circumstances. Consequently, the question is whether the legal system should provide any incentive to these forms of collective action on the basis of the "public interest" nature of the goals being pursued, and, if so, what form these incentives should take. These issues will be explored in later sections.

\footnotetext{
236 Ibid., pp. 159-161; see also, more recently, Kahan, op. cit. (fn. 212), p. 2; see also p. 8-9.

237 Ibid., p. 10.

238 Ibid., pp. 12-13.

239 Ibid., p. 10; see also Olson, pp. 166-167.
} 


\section{COLLECTIVE ACTION IN THE CONTEXT OF PRIVATE ANTITRUST ENFORCEMENT: THEORETICAL ISSUES}

\subsection{Private Antitrust Enforcement as a "Public Good": the Rationale of Collective Action}

Section 4 gave a brief account of Olson's theories underpinning the "logic" of collective action and illustrated how the size of a group can have a significant impact on its ability to "aggregate" into a collective organization and thereby organize a "common" strategy for action. Olson highlighted the two key issues of how this "latent" group can, in the absence of incentives affecting individual members, be "kicked into action" and how, once this outcome is achieved, such a common strategy can be brought to fruition by means of a form of efficient "management". To this end, he proposed a theoretical framework in which the only way that the former objective could be achieved was by offering a "selective incentive" to individual members, and, in addition to the "collective good", a non-collective one as a way of "bribing" the individual into joining in with the group and so adhering to the common action. In this specific context it was also shown that external action, such as governmental intervention, could influence the effectiveness of these incentives.

Against this background it was argued that although Olson's theoretical framework was not reflected fully in all forms of collective action, it provided a useful blueprint through which the functioning of many collective organizations (whether "formal" or not) could be described. His analysis, however, is necessarily subject to important limits: it was argued that taking collective action in a number of areas, especially on the part of large groups, may be inherently difficult and therefore infrequent in a number of cases. Olson himself singled out consumers as a category of "silent sufferers" who often remained passive even though they had suffered considerable harm, and therefore were unable to engage in any meaningful collective action for the purpose of protecting important "public interest" goals, such as product safety. In this specific respect, it is suggested that similar considerations may apply for those consumers who have been adversely affected by the consequences of anti-competitive practices, especially in jurisdictions where the take-up of these actions has been poor. Thus, the question is, what incentives can be introduced to encourage the members of the large group of the "victims" of anti-competitive behaviour to take collective legal action (or to join an existing lawsuit) against a common tortfeasor? 
It should be remembered that the "diffuse" nature of "antitrust harm" means that the latter is liable to affect a large number of potential claimants in a similar way (although the size of individual claims may differ due, inter alia, to the terms of individual legal relationships). ${ }^{240}$ In this context, it was also illustrated how these claims are often of low value individually, thus making it "uneconomical" for each prospective claimant to pursue them in the courts. Thus, it was suggested that, taken together with the "covert" nature of anti-competitive practices, as a result of which their litigation tends to be costly and uncertain, antitrust victims often remain "passive" and "disenfranchised" vis-à-vis any attempt to seek redress for their injuries. ${ }^{241}$ Against this background it was argued that collective litigation could provide an effective response to the implications of the "negative outcome" of this trade-off since it would reinforce the "litigation posture" of the plaintiffs and also reduce the financial burden associated with pursuing the claim, thus safeguarding the value of the prospective award. ${ }^{242}$ In addition to pursuing objectives of restorative justice, collective antitrust litigation was considered to be capable of boosting the deterrence of future infringements, thereby supplementing the role of the public authorities in this area. ${ }^{243}$

Recourse to group proceedings was also seen as capable of addressing several important concerns, such as the "pro-defendant bias" associated with repetitive litigation and the need to "administer wisely" the judicial resources required in complex and fact- and evidence-intensive cases, for which an accumulation of very similar lawsuits would be particularly damaging. ${ }^{244}$ In this context collective action in "public interest" litigation presents significant advantages in terms of cost reduction, since it allows for the exploitation of the "economies of scale" associated with the litigation of torts having a "diffuse" impact on society, that is,

240 Supra, section 2; see also Commission 2008 Staff Working Paper accompanying the White Paper on antitrust damages, COM (2008) 165 final, para. 6.

241 See e.g. 2008 Impact Assessment Document, para. 32, see also paras 37-38.

242 Ibid., para. 31.

243 See e.g. Hawaii v Standard Oil Co, 405 US 251 (1972), p. 266; also Zenith Radio Corp v Hazeltine Research Inc, 395 US 100 at 130-131; in the UK, see e.g. Devenish Nutrition Ltd v Sanofi Aventis SA, [2007] EWHC 2394, para. 29, 48-50; for commentary, see, inter alia, J.C. Coffee, "Rescuing the private attorney general: why the model of the lawyer as bounty hunter is not working" (1983) 43 Md. L Rev 215 at 227.

244 Ibid., pp. $260 \mathrm{ff}$. 
affecting a large number of would-be plaintiffs. ${ }^{245}$ Seen in this context, aggregating numerous and individually "low-value claims" all arising from a common core of factual and legal questions was regarded as a tool for boosting access to the courts as well as securing the efficient deployment of limited resources in the adjudication of complex and uncertain cases. ${ }^{246}$ Thus, in respect of the former objective, it was argued that the "economies of scale" generated by class litigation would be especially appealing to counsel who would "welcome" the ability to spread the risk arising from taking on these cases and thereby be "convinced" to file the action on behalf of the class. ${ }^{247}$ And, in respect of the latter goal, the ability to adjudicate otherwise "repetitive" actions "en masse" in one set of proceedings enabled the courts to "save resources" and also encouraged them to "invest" sometimes significantly in time and economic resources so as to be in a position to deliver more accurate and more reliable judgments. ${ }^{248}$

Aggregating a wide number of individually small lawsuits into a large one was shown to have a positive impact on the fairness of adjudication more generally, by reducing the risk of "defendant bias" associated with repetitive litigation ${ }^{249}$ and preventing "deep-pocketed" defendants from exploiting the economies of scales associated with fighting substantially the same low value claim against a large group of plaintiffs acting individually. ${ }^{250}$ It was argued that by contrast with individual litigation,

245 Rosenberg, "The regulatory advantages of class action”, in Viscusi (ed.), Regulation Through Litigation, op. cit. (fn. 73), pp. 245-247.

246 Ibid., pp. 263-264.

247 Ibid., pp. 279-281. See e.g. Baye and Wright, "Is antitrust too complicated for non-specialist judges? The impact of economic complexity and judicial training on appeals" (2009) George Mason Law \& Economics Research Paper No 09-07, available at: http://papers.ssrn.com/sol3/papers.cfm?abstract_id= 1319888, pp. 2-4; see also pp. 5-6, 12-16.

248 Rosenberg, "The regulatory advantages of class action", in Viscusi (ed.), Regulation Through Litigation, op. cit. (fn. 73), pp. 279-281. See e.g. Baye and Wright, "Is antitrust too complicated for non-specialist judges? The impact of economic complexity and judicial training on appeals", op.cit. (fn. 249), pp. 2-4; see also pp. 5-6, 12-16.

249 Rosenberg, op. cit., (fn. 73), pp. 270ff.

250 See e.g. Lang, "Class actions and the US antitrust laws: prerequisites and interdependencies of the implementation of a procedural device for the aggregation of low value claims" (2001) 24 W Comp 285 at 286-287; also 2008 White Paper, paras 2.1-2.2; see also 2008 Impact Assessment Document, para. 51, see also para. 165. Most recently, Commission Staff Working Document: Public Consultation - towards a coherent European approach to collective redress, SEC(2011) 173 final (hereinafter referred to as the 2011 Consultation document), 
the collective adjudication of these cases would contribute to redressing the "imbalance of power" (especially financial) existing between individual victims and powerful tortfeasors who, faced with a more "matching counterpart" - namely the group as a whole - would no longer be able to minimize the "cost per claim" and consequently to redirect these spare resources to adopting a powerful litigation "posture". ${ }^{251}$

It is therefore apparent from the forgoing analysis that aggregating small claims into a "mass" competition action would secure the effective and fair adjudication of these cases as well as increase the access to justice for small claim litigants ${ }^{252}$ for the purpose of granting effective compensation and of securing deterrence of future unlawful behaviour. ${ }^{253}$ Consequently, a number of questions arise as to how lodging individually low value claims as a collective action can be encouraged while at the same time respecting the broader principles governing the fair and effective adjudication of civil disputes. ${ }^{254}$ The next section will consider whether the "by-product" doctrine can offer any useful insights as to how this often heterogeneous group of potential claimants, such as the individuals and firms affected by a "diffuse" antitrust injury, can be "mobilized" for the purpose of accessing collectively the judicial system and thereby seek protection of their common interests.

\subsection{Mobilizing Small Claimants in Antitrust Lawsuits: "Latent Groups" and "By-products" ...}

The previous section argued that the "public good" nature of competition enforcement, together with the concern for ensuring compensation for damages arising from unlawful restraints on trade, in accordance with the principle of restorative justice, provide a powerful justification for creating a framework for the collective redress of harm arising from anti-competitive practices. It was illustrated that the introduction of such a framework would bring considerable benefits by allowing plaintiffs, who are usually the more disadvantaged party in this type of litigation, to exploit economies of scale arising from treating almost identical complex

available at: http://ec.europa.eu/justice/news/consulting_public/0054/Consultation paperCollectiveredress4February2011.pdf, paras 8-9.

251 See Rosenberg, op. cit. (fn. 73), p. 272.

252 Ibid., p. 303.

253 Ibid.

254 See, inter alia, J. Wootton, "Comment on Rosenberg", in Viscusi (ed.), op. cit. (fn. 73), pp. 304-309; also, mutatis mutandis, 2011 Joint Information Note, op. cit. (fn. 7), paras 20-22. 
claims together and thereby counteract the "pro-defendant bias" characterizing this and other "mass torts". ${ }^{255}$ Collective litigation is also likely to boost the efficient adjudication of these cases by avoiding repetitive litigation and thereby preventing the otherwise "wasteful" duplication of effort. ${ }^{256}$

Against this background, the question is how the legal system can seek to "mobilize" this large group of would-be plaintiffs into taking action to protect their own interests and, as a consequence, increase the deterrence of the competition rules: in particular, can the "by-product" doctrine articulated by Olson can provide any insights into how to encourage collective litigation in this area? It is recalled that antitrust injuries are often "diffuse" - in other words, despite stemming from the same set of facts, they are often likely to affect large sections of the population in different ways and with different intensity. As a result, it could be argued that those adversely affected by their consequences are very likely to form a "latent group", that is, a group which is so large that the actions taken by individual members are unlikely to perceptibly affect the interests of all the other members. In this context, Olson argued that individual members could only be "mobilized" into taking a new (or adhering to an existing) collective action by the group offering to each of them a non-collective, excludable good, which became only available to them as a result of participation and whose supply represented the "by-product" of the institutional activity pursued by the group as a whole. It may, therefore, legitimately be asked what incentives can be created for the purpose of promoting new collective antitrust litigation: in other words, what type of "by-product" (if any) can be offered to potential plaintiffs in order to encourage them to either initiate or to participate in collective legal proceedings designed to recover losses arising from anti-competitive behaviour?

It is argued that the answer to this question lies in the very objectives pursued by private competition enforcement, which vary from jurisdiction to jurisdiction. It was illustrated in Part I of this chapter that, unlike in the US where antitrust litigation was seen as a deterrent against future infringements, alongside being a "restorative justice" tool, the promise of "treble damages", especially if taken together with other measures aimed at "minimizing" the "threat" of costs and legal fees, acted as a very powerful incentive to sue. Thus it could be suggested that,

255 See e.g. Hawaii v Standard Oil Co, 405 US 251 (1972), p. 266; see also Rosenberg, op. cit. (fn. 73) at 246-247.

256 Lang op. cit. (fn. 112) at 286. 
in a jurisdiction where a damages multiplier and rules derogating from the traditional "loser pays" principle are in force, the perspective of being able to claim "enhanced" damages, without at least some of the "pressure" represented by the liability for court costs and legal fees, could represent such a "by-product" for individuals choosing to adhere to a collective action. ${ }^{257}$ This position can, however, be contrasted with the view of competition damages adopted by the Court of Justice of the EU who has consistently held that competition litigation should play a mainly compensatory role, albeit one "auxiliary" to the deterrent function vested with public enforcement. ${ }^{258}$

However, how individual "victims" can be "coerced" (albeit indirectly) into initiating a new or participating in an existing collective lawsuit to obtain redress for the consequences of anti-competitive behaviour constitutes a separate (albeit related) question that must be answered in light of the "practical" features of competition litigation. ${ }^{259}$ It was illustrated in an earlier section that the "negative value" of these claims, taken individually, often discouraged potential plaintiffs from lodging a claim with the courts. It was argued that, faced with a trade-off between the small value of their claim and the potentially high costs and significant difficulties associated with litigating it, the victims of competition infringements would be likely to remain "passive" rather than to take the affirmative step of suing the defendant. Against this background, it is argued that promising to each would-be plaintiff a level of compensation, in the event of a successful claim, which is both "meaningful" (in the sense of not being "excessively dented" by the impact of the costs associated with litigating the claim) and effective (namely, capable of reflecting both the economic loss and the loss of earnings suffered as a result of the infringement) could play the role of "selective incentive" acting to indirectly coerce them into participating in the group legal proceedings. ${ }^{260}$

257 See, inter alia, Elzinga and Breit, op. cit. (fn. 118), pp. 93-95; see also Trebilcock and Roach, op. cit. (fn. 121), pp. 493-494.

258 Case C-295/04, Manfredi, op. cit. (fn. 36), paras 59-60, see also para. 91; also, inter alia, 2008 White Paper, para. 2.1.

259 See e.g. European Parliament Resolution, op. cit. (fn. 6), para. 6.

260 See e.g. 2008 Commission White Paper Impact Assessment Document, para. 51; for commentary, see e.g. Komninos, "New prospects for private enforcement of EC Competition law: Courage $v$ Crehan and the Community right to damages" (2002) 39 CML Rev 447, especially pp. 474-476; also, Chieu, "Importing class actions in the European Union?" (2010) 18 Cardozo J Int'l 
Although it is acknowledged that the competition damages remedy provided by EU law responds to the widely accepted principle of restorative justice, which applies not only in the interest of individual claimants but also for the benefit of society as a whole, it is suggested that the promise of a "meaningful" award could also act as a "byproduct" vis-à-vis these "general", "institutional" objectives, and thereby as a means of "mobilizing" individual potential plaintiffs into adhering to a collective lawsuit. ${ }^{261}$ It could be argued that only by adhering to a collective lawsuit would individual plaintiffs be able to obtain compensation which, taking into account the costs and difficulties associated with litigating these claims, would redress the injury suffered as a result of the infringement without involving the otherwise significant efforts (especially financial) associated with pursuing these claims individually. ${ }^{262}$ It is therefore submitted that, seen in this light, collective legal action becomes for each member of the "latent group" of individuals adversely affected by the consequences of prima facie anti-competitive behaviour a rational option for the purpose of obtaining relief of their injuries, since it would allow them to obtain compensation which, despite remaining of relatively small value, is not so reduced, as a result of the impact of the costs associated with this litigation, as to no longer be worth pursuing at all. ${ }^{263}$

In light of the foregoing analysis, it may be concluded that the promise of "meaningful" and "effective" compensation for losses caused by the impact of anti-competitive behaviour can act as an incentive for would-be plaintiffs, who would otherwise remain "passive" in the face of these "negative value" losses, failing to either initiate or to adhere to existing collective lawsuits designed to redress the consequences of anticompetitive conduct. The next sections will therefore consider the question of how these objectives can be realized in practice. How potential plaintiffs can be put in the position of adhering to existing or contemplated legal proceedings and how the latter can be conducted in a way that respects due process principles will be examined. In addition the question will be raised of how the overall fairness of these representative and inherently complex proceedings can be balanced against the demands

Comp L Rev 123; Jevons et al., "Antitrust damages quantification", (2010) 3(2) G Comp L Rev 82.

261 Jevons et al. op. cit. (fn. 261), especially pp. 86-87.

262 See e.g. 2008 Impact Assessment Document, para. 168.

263 See e.g. Hensler, op. cit. (fn. 78), pp. 17-18; also Rosenberg, op. cit. (fn. 73), pp. 243-245. 
of efficient and speedy adjudication, in the interest of the sound administration of justice.

\subsection{And What About the "Sound Administration of Justice"? Aggregating Civil Competition Claims as a "Balancing Exercise"}

The previous sections illustrated that competition litigation represents an "ideal candidate" for collective action in the civil courts, on the ground of the "public interest" nature of the competition rule and of the potential advantages that group adjudication can have for access to justice, sound judicial decision-making and overall fairness and efficiency in the resolution of complex cases. It was also argued that the perspective of being able to obtain "meaningful compensation" can represent a strong incentive for "mobilizing" often large groups of victims into starting a (or joining an existing) new action, and thereby lead to the restoration of the antitrust harm they suffered. However, it is also clear that representative litigation, in whatever area of the law, presents significant challenges for the "machinery of justice" as well as, more generally, for the guiding principles of civil litigation. ${ }^{264}$

It has often been argued that allowing these actions to proceed collectively would exacerbate the "detachment" existing between the claim and the plaintiff, who would no longer be in control of the litigation itself; it was also feared that, by limiting the ability of the defendant to raise defences that are individual to specific members of the group being represented in the action her right to a "fair trial" would be curtailed. ${ }^{265}$ Overall, it was submitted that adopting a decision as to whether to authorize the use of representative litigation requires a careful balancing of interests and in particular requires the reconciliation of the demands of greater access to justice with the need to maintain appropriate standards of due process, to the benefit of all parties. ${ }^{266}$ These concerns were clearly expressed by, among others, Lord Woolf, who in his Report on Access to Justice in England and Wales, stated that although collective

264 See, inter alia, Newberg, 4th edn., para. 18.01; see also in England and Wales, Lord Woolf, Final Report to the Office of the Lord Chancellor on Access to Justice in England and Wales (hereinafter referred to as "Woolf Report"), 1996, available at: http://webarchive.nationalarchives.gov.uk/+/http://www.dca. gov.uk/civil/final/contents.htm, chapter 17, para. 2.

265 Woolf Report, chapter 17, para. 9; see also Mulheron, op. cit. (fn. 132), p. 55 .

266 Woolf Report, chapter 17, paras 11-12; see also Mulheron, op. cit. (fn. 132), pp. 43-45 and 57. 
legal actions were undoubtedly capable of delivering appreciable improvements in access to the court system and in increasing the efficiency of adjudication, they involved a derogation from key constitutional values of personal autonomy, including one's right to control litigation affecting one's own interests, and of fairness in adjudication. ${ }^{267}$

Against this background, the question is how to balance these concurring interests so as to design a framework for collective redress that ensures full access to justice to all potential plaintiffs - especially those who, due to the low value of their claim, would have little or no incentive to initiate litigation - and respects principles of due process. On this point, Mulheron argued that in assessing the merits of each collective redress option, the emphasis should be not so much on seeking a "perfect" system, but on making a "shift from perfection to proportionality".268 Consequently, she suggested that any form of collective legal action should be devised in a way that keeps the percentage of error in decision-making to a minimum and at the same time reduces the costs associated with wider access to the courts, especially by reducing the incidence of repetitive litigation. ${ }^{269}$

It was added that recourse to collective litigation would not only have objective advantages for the administration of justice as a whole; it would also be fully consistent with the demands of a mass market society, in which product standardization often leads to the total "absence of a one-to-one [...] connection between the consumer" and the supplier of widely available goods or services. ${ }^{270}$ Accordingly, it was argued that in these circumstances should damages occur as a result of the usage of these "standardized" products, it would be unrealistic to expect that liability could be determined in each case via individual litigation. ${ }^{271} \mathrm{By}$ contrast, collective proceedings would enhance access to justice, secure finality and increase efficiency in adjudication by "replacing" a "myriad" of small, repetitive claims with one collective lawsuit. ${ }^{272}$

This view of collective litigation as the "appropriate response" to the demands of compensating torts occurring within the mass market society, including those arising from the infringement of the competition rules,

\footnotetext{
267 Woolf Report, chapter 17, para. 12.

268 Ibid., paras 8 and 11; Mulheron, op. cit. (fn. 132), pp. 52 and 56.

269 Ibid; see also Fiss, "The political theory of the class action" (1996) 53

Wash. \& Lee L Rev 21 at 25-26.

270 Davis, "Toward the proper role of mass tort class action" (1998) 77

Oregon L Rev 151 at 159.

271 Ibid., p. 161.

272 Ibid., pp. 159-160.
} 
seems to have been endorsed by, among others, the US Supreme Court. It was held in American Pipe that antitrust class actions arising from the impact of the same prima facie anti-competitive practice avoided "unnecessary filings of repetitious claims and motions", thus providing a "superior" avenue for the resolution of disputes that are common to a large number of potential litigants. ${ }^{273}$ In this context, the Court added that the requirements that the claim brought by the named plaintiff on behalf of the "unnamed" parties be "typical" to the class - that is, that the interests that the class representative seeks to pursue be "aligned" with those of the class as a whole - and that the named plaintiff be able to "adequately represent the class contributed to the overall fairness of the proceedings. ${ }^{274}$

In light of the foregoing analysis it is clear that collective adjudication provides an efficient avenue to access the courts for the victims of "diffuse injuries". However, the discussion conducted so far has also highlighted the equally pressing concerns for keeping any "inroads" into the right of "personal autonomy" of every litigant to a minimum, and in particular for ensuring that those limitations are no more than strictly necessary to secure the much vaunted "efficiency gains" of collective litigation for the administration of justice as well as for the overall effectiveness of "public interest" legislation. ${ }^{275}$ In other words, how can a collective lawsuit be managed so that the interests of the class to the fair, timely and overall certain adjudication of a dispute affecting its members are not unduly "sacrificed" for the benefit of the efficient and speedy adjudication of "public interest" disputes?276

273 American Pipe \& Construction Co Ltd v Utah, 4141 US 538 at 550-551; see also Philadelphia Electric Co and others $v$ Anaconda and others, 43 FRD 452 at $458-459$.

274 Ibid., at 551.

275 See, inter alia, In Re: Community Bank of Northern Virginia, 622 F.3d 275 at 292; also, mutatis mutandis, Greenfield v Villager Industries, 483 F.2d 824 at 832. For commentary, see e.g. Mulheron, op. cit. (fn. 132), p. 55-56. See also, more generally, Thomas, "Ubi just, ibi remedium: the fundamental right to a remedy under due process", the University of Akron School of Law Public Law and Legal Theory working paper series no 04-03, available at: http:// papers.ssrn.com/sol3/papers.cfm?abstract_id=564302, pp. 5-6.

276 See e.g. Mullane v Central Hanover Bank and Trust Co, 339 US 306, 314-315; for commentary, inter alia, Mulheron, op. cit. (fn 132), pp. 321-322; see also pp. 337-340; also see, inter alia, Issacharoff, "Preclusion, due process and the right to opt out in class actions", Columbia University Law School Public Law and Legal Theory working paper group, paper no 02-40, available at: http://papers.ssrn.com/sol3/papers.cfm?abstract_id=306001, pp. 2-3; Lahav, 
It is submitted that the answer to this question varies, and sometimes it does so substantially, from jurisdiction to jurisdiction: as will be illustrated in greater detail in Part II, the "opt-out class actions" available to antitrust victims in the US rely on the continuing supervision exercised by the trial court which at key stages of the proceedings ensures that the claim is litigated fairly and efficiently as well as in the full interests of the class members. Thus, in this context the "certification inquiry" seeks to ascertain that each complaint is suitable for being adjudicated via representation on the ground that, inter alia, the "common questions" of law and of fact can be answered via "common proof", that is, via evidence and a common method for its assessment that are equally decisive for all the members of the group being represented. ${ }^{277}$

Another important factor in striking this balance concerns the role of class counsel. As will be discussed in more detail in the following section, due to the inevitable "detachment" between the lawyer acting for the class and his or her "clients" that results from certification and from the public interest nature of these claims, the former enjoys significant independence in conducting litigation; consequently, it has often been argued that this considerable autonomy could engender the risk that class counsel may act in pursuit of his or her own financial interests (for example, by "running up the hours") and thereby adversely affect those of the class. On this point, it should be emphasized that to respond to this very concern the rules on class litigation in the US empower the trial court to review the "reasonableness" of the fees awarded to class counsel $^{278}$ and, if the dispute is settled out of court, to scrutinize and approve the agreement reached on behalf of the class with the defendant. $^{279}$

It should be noted that broadly similar mechanisms to ensure the "fair and good management" of collective lawsuits are also present in other legal systems: for instance, in Portugal the legislation on "Popular actions" expressly empowers the trial court to, inter alia, scrutinize

"Fundamental principles for class action governance" (2003-2004) 37 Ind. L Rev 65 at $75-76$.

277 Infra, Part II, Chapter 3; see e.g. In Re: Hydrogen Peroxide Antitrust Litigation, 552 F3d 305, especially at 310-312.

278 Infra, see Part II, Chapter 4, especially section 3.2; see, inter alia, City of Detroit v Grinnell Corp, 495 F2d 448 at 459.

279 Infra, see Part II, Chapter 4, section 3.3; see, inter alia, mutatis mutandis, McDaniel v County of Schenectady, $595 \mathrm{~F} 3 \mathrm{~d} 411$ at 418; also In Re: NASDAQ Market Makers Antitrust Litigation, 187 FRD 465 at 487-488. 
settlements negotiated by counsel on behalf of the class. ${ }^{280}$ Furthermore, the UK government in its 2013 response to the consultation on private actions in competition law similarly stated that it would confer on the trial court the power to, inter alia, scrutinize the reasonableness not only of out of court settlements but also of the fees to be paid to the class lawyer as part of the deal. ${ }^{281}$

In light of the foregoing, it is concluded that judicial checks represent perhaps the most frequent mechanism through which collective civil proceedings can be managed in a way that reconciles the public interest to the full and efficient access to justice and the principles of overall fairness that should govern the adjudication of civil matters. It is emphasized that striking an appropriate balance among these concurrent interests ensures that that the right of the claimants to maintain personal and direct "control" over litigation affecting their interests is only limited when these limits can yield clear benefits for the overall administration of justice. ${ }^{282}$ It is, however, apparent from the discussion that the existence of strong safeguards attending the role of counsel throughout the proceedings, for the purpose of protecting the integrity the rights of the class, is regarded as being equally necessary in light of the often considerable "freedom of action" enjoyed by him or her in the course of the litigation. The next section will therefore briefly address the role of class attorney in the context of collective litigation in general and as regards the "management" of these proceedings in particular.

280 Infra, Part II, Chapter 7, section 3.4; see Sousa Antunes, "Class actions, group litigation and other forms of collective litigation", report submitted to the Centre for Socio-Legal studies, University of Oxford (2007), available at: http://globalclassactions.stanford.edu/content/class-actions-group-litigation-andother-forms-collective-litigation-portugal, pp. 24-25.

281 UK Government Department of Business, Innovation and Skills, "Private actions in competition law: a consultation on options for reform - Government response", February 2013, available at: https://www.gov.uk/government/uploads/ system/uploads/attachment_data/file/70185/13-501-private-actions-in-competitionlaw-a-consultation-on-options-for-reform-government-response1.pdf, see especially sections 5.71-5.72; see infra, Chapter 6, see especially section 3.2ff.

282 See e.g. Mullane v Central Hanover Bank and Trust Co, 339 US 306, 314-315; for commentary, inter alia, Mulheron, op. cit. (fn 132), pp. 57 and 321-322; see also pp. 337-340; see also Impact Assessment Document accompanying the 2008 White Paper, paras 97-99. 


\subsection{Class Counsel as "Private Attorney General"? Between Facilitating Access to Justice and Protecting the Rights of the Class Members}

The previous sections examined a number of theoretical questions concerning collective actions generally and group civil litigation in particular. Section 5.3 especially highlighted the role of the trial court as a key actor in ensuring that collective proceedings can be conducted both efficiently and fairly. At the same time, however, it was argued that the relative "independence" with which the named plaintiff and especially her counsel could "manage" the litigation, while being in principle consistent with the need of furthering "common interests" and also necessary for stimulating new litigation, could actually lead to a significant degree of detachment vis-à-vis the class members. Against this background, ensuring that class counsel be subjected to appropriate checks as to her conduct vis-à-vis the class and its interests was regarded as indispensable for maintaining the sound administration of justice in these cases without prejudicing the overall fairness and integrity of the rights of the litigants.

It is noted that many of these questions will be discussed in more detail in Part II, Chapter 4. However it is indispensable to point out already at this very early stage that the legal systems that allow for collective litigation embed these safeguards vis-à-vis counsel's "opportunistic behaviour" already at the outset of the proceedings, that is at "admissibility stage", when deciding on whether to allow the case to proceed via representation. This is the case, for instance, in the US, where Rule 23(b)(3) FRCP expressly enumerates the concept of "adequacy of representation" as an essential requirement for certification of class complaints. ${ }^{283}$ The Court of Appeals' 2nd Circuit explained in Kirkpatrick that while an action is nominally lodged by one of the class members on behalf of all the others, it is usually class counsel that takes the lead in conducting the actual litigation, with the named claimant being put in a "passive position". ${ }^{284}$ Ensuring that counsel is "skilled and competent" as part of the certification scrutiny therefore ensures appropriate professional standards in the litigation of the dispute. ${ }^{285}$

In addition, and perhaps more importantly, this requirement seeks to prevent attorneys holding interests in conflict with those of the class or

\footnotetext{
283 See e.g. Kirkpatrick v JC Bradford \& Co, 827 F2d 718 at 727.

284 Ibid.

285 Ibid; see also e.g. Re: Catfish Antitrust Litigation, 826 F Supp 1019 at 1037.
} 
of any of its members from taking advantage of the "detachment" vis-à-vis the latter and thereby being able to fulfil "opportunistic" and "profit-maximising" motives via the conduct of litigation. ${ }^{286}$ Thus, to grant certification when counsel does not display any of these qualities would risk impairing the overall fairness of the proceedings by creating the conditions for "unscrupulous" counsel to damage the interests of the class for his or her own gain. 287

More generally, it is submitted, in light of the foregoing, that the "admissibility stage" of class proceedings already provides an important opportunity for "vetting" counsel, so as to avoid class litigation being managed in a way that does not respond to the interests of the class. However, controlling the professional "qualities" of counsel and the absence of conflict of interests at the beginning of litigation may not be sufficient to secure appropriate standards of protection for the class members' interests throughout the course of the proceedings. ${ }^{288}$ On this point, it should be emphasized that, as the US experience has shown, class counsel acts to a significant extent independently of any "control" that her client (namely the class) may be able or willing to exercise. ${ }^{289}$ Thus, it is argued that although stimulating the bringing of these new cases may be justifiable in light of the demands of the "public interest" pursued by this type of litigation, it is indispensable to subject counsel to the control of the trial court throughout the proceedings.

This tension was aptly captured by, among others, the US Supreme Court in a collective securities lawsuit. ${ }^{290}$ It was held that while the advantages of the class action device as a means of lodging actions that would not have been brought otherwise are very clear, the "potential for misuse of the action" remained "obvious". ${ }^{291}$ On this point, it was held that such a risk originated from the dependency of these actions on the willingness of the legal profession to take them before the court, a

286 Ibid; see also Re: Discovery Zone Securities Litigation, 169 FRD 104 at 108.

287 See, inter alia, mutatis mutandis, Surowitz $v$ Hilton Hotel Corp and others, 383 US 363 at 367.

288 See Kirkpatrick, op. cit. (fn. 283) at 726-727; see also e.g. Olson, op. cit. (fn. 162), pp. 55ff.

289 See e.g. Kirkpatrick, op. loc. ult. cit.; also Rubinstein, "Why enable litigation? A positive externalities theory of the small claims class action", UCLA School of Law Public Law and Legal Theory research paper series, Paper No 06-10 (2004), available at: http://papers.ssrn.com/sol3/papers.cfm?abstract_ $\mathrm{id}=890303$, pp. 6-7.

290 Deposit Guaranty National Bank v Roper, 445 US 326.

291 Ibid., at 337-338. 
"willingness" which, in turn, was strongly linked to the economic incentives offered to them, among which contingency fee agreements featured prominently. ${ }^{292}$ The court therefore held that while "public interest" litigation, including the lodging of antitrust cases, could only be feasible thanks to the involvement of class counsel, fuelled by appropriate "economic incentives", it was indispensable that his or her role should be kept "in check", not only at the start but also during the proceedings and especially when lawyers' fees were assessed and awarded. ${ }^{293}$

In light of the foregoing analysis it is suggested that a degree of "detachment", which sometimes can be significant, between class counsel and her "collective client" is an inevitable consequence of the nature of group representative action. ${ }^{294}$ However, as was aptly put by the US Supreme Court, it is indispensable that appropriate forms of "judicial checks" of her role should be made available so that the demands associated with having to run "public interest litigation" can be reconciled with both the need to protect the integrity of the interests of "disenfranchised" unnamed plaintiffs to recover appropriate compensation for the injuries and the demands of the fair adjudication of these cases. $^{295}$

These questions will be addressed in greater detail in Part II. Nonetheless, it is already clear that class litigation, especially if undertaken in "public interest" areas of the law, necessarily entails a significant degree of autonomy of class counsel vis-à-vis the class as a whole, as a result of which it is the class attorney and not the named plaintiff who takes the lead in the litigation. ${ }^{296}$ While it is acknowledged that the enjoyment of a significant degree of independence in the "management" of the action plays an important practical role in boosting the litigation rate as well as in making these proceedings an effective complement to public enforcement, it is also clear that this creates a risk of counsel being induced to adopt "opportunistic" behaviour to the detriment of the class. ${ }^{297}$ Against

\footnotetext{
292 Ibid., at 338-339.

293 Ibid; for commentary, see also Coffee, "Rescuing the private attorney general: why the model of the lawyer as the bounty hunter is not working" (1983) 42 Maryland L Rev 215 at 220.

294 Ulen, "An introduction to the law and economics of class action litigation" (2011) 32(2) EJL \& E 185 at 191-193.

295 See Coffee, op. cit. (fn. 293), pp. 234-236 and 247-248.

296 See Roper, op. cit. (fn. 290) at 339; see also Coffee, op. cit. (fn. 293) at 220.

297 Coffee, op. cit. (fn. 293) at 221-222.
} 
this background, it is therefore argued that appropriate checks on counsel's ability to conduct litigation fairly and efficiently, to be performed at the start and towards the conclusion of the proceedings, should be in place to guarantee the continuing adherence to appropriate standards of due process and efficient adjudication throughout the case. ${ }^{298}$ In this specific context, it is submitted that the power of the trial court to appraise the "reasonableness" of the fees claimed by counsel is especially important since it aims to prevent the latter "running up the hours" just to boost her recompense but without any advantage being accrued to the class. ${ }^{299}$

In light of the foregoing discussion it may be concluded that alongside the question of how large groups of individuals sharing "common interests" should be aggregated, the issue of the "management" of collective litigation presents significant challenges for the maintenance of appropriate standards of sound and fair administration of justice in "mass tort" cases. It is acknowledged that the public interest can justify, if not sometimes require, that private actors, such as class counsel in the US class actions' experience, take the lead in managing these cases. However, it is clear that in these circumstances the courts should act as "gatekeepers" in these actions: in other words, it should be incumbent on the judge to decide whether a specific claim should be amenable to being decided via representation. In this context, the powers of the court should not only be limited to scrutinizing the "adequacy of counsel" to represent the class, on the ground that there is no "conflict of interest" between them. They should also allow the trial judge to remain "vigilant" at other key stages of the litigation (for example, when lawyers' fees are awarded or when a non-judicial settlement is declared binding) to avoid the risk that class counsel, out of a wish to pursue personal gain, may collude with the defendant to the detriment of the class as a whole.

298 See Roper, op. cit. (fn. 290), pp. 338-339; see also Ulen, op. cit. (fn. 294), pp. 192-193.

299 See e.g. Coffee, op. cit. (fn. 293), at 247-248. 


\section{6. "MOBILIZING" PROSPECTIVE ANTITRUST LITIGANTS THROUGH COLLECTIVE COMPETITION LITIGATION - TENTATIVE CONCLUSIONS}

Part 2 of this chapter attempted to discuss, albeit briefly, the question of what "drivers" can guide effective collective action. Relying on the theoretical framework developed by Mancur Olson, it was argued that in "latent groups", such as the one made up of those individuals that have been adversely affected by "diffuse" antitrust injuries, it is indispensable to provide an adequate "by-product", that is, a good which is both excludable and indivisible, in order to "mobilize" individual members of that group into adhering to the collective action destined to attain the "collective good". In addition, the existence of an "efficient" form of "management" of the collective action emerged as a key factor in ensuring that the latter attain its "institutional" goal. Against this background, the chapter suggested that in order to render collective redress an effective mechanism to secure the goals of private antitrust enforcement, that is, deterrence and the restoration of "unjust harms", this by-product should be represented by the perspective of gaining effective and meaningful compensation for the damage suffered by those aggrieved by unlawful behaviour. Appropriate rules should also be put in place to ensure that the "management" of these actions is "effective", that is, capable of ensuring that the collective lawsuit can achieve its objectives.

However, this discussion has highlighted significant tensions vis-à-vis other, equally relevant principles, such as the due process rights of both litigants, the personal autonomy of individual plaintiffs and their legitimate interest to "control the suit". It was argued that ultimately devising any collective redress mechanism should seek to achieve a "fair balance" between the right of access to justice for all litigants, despite the small size of their individual claim and in the face of their limited financial resources, and the sound administration of justice and overall fairness of trial. For these reasons, the chapter argued that while civil litigation represents an important and sometimes indispensable complement to public enforcement of "public interest statutes", appropriate safeguards should be put in place to ensure that those "in charge" of the management of these actions (class counsel especially) do not pursue their own interests as opposed to those of the group they represent. The existence of a clear set of rules governing the "certification" of group complaints, that is, the adoption of a decision allowing these claims to be litigated via representation and the conferral to the trial court of supervisory powers at 
key stages of the litigation, emerge as indispensable features for civil proceedings which are not just "efficient" but also "fair".

The next chapters will examine how these competing values and interests have been reciprocally balanced in the collective redress schemes existing in individual jurisdictions. It will be shown that while each of these schemes represents one possible solution to the question of how to achieve the outcome of "proportionality" among the various interests outlined above, all present varying degrees of effectiveness in respect to the achievement of the collective good they pursue. Thus the question which will be ultimately addressed is whether the European Commission, in adopting a marked preference for certain types of collective redress mechanisms, is likely to achieve the twin goals of antitrust deterrence and of restorative justice in the most effective way. 